\title{
BRINES IN DEEP HORIZONS OF THE UDACHNAYA KIMBERLITE PIPE
}

\author{
S. V. Alekseev1, L. P. Alekseeva1, ${ }^{1}$, A. S. Gladkov ${ }^{1}$, N. S. Trifonov ${ }^{3,4}$, \\ E. V. Serebryakov' ${ }^{1}$, S. S. Pavlov ${ }^{5}$, A. V. Il'in' 6
}

${ }^{1}$ Institute of the Earth's Crust, Siberian Branch of RAS, Irkutsk, Russia

${ }^{2}$ Irkutsk State University, Irkutsk, Russia

${ }^{3}$ Tomsk Division of A.A. Trofimuk Institute of Petroleum Geology and Geophysics, Siberian Branch of RAS,

Tomsk, Russia

4 Tomsk Polytechnic University, Tomsk, Russia

${ }^{5}$ Udachny Mining and Processing Division, Public Joint Stock Company "ALROSA", Udachny, Russia

${ }^{6}$ Vilyui Geological Prospecting Expedition, Public Joint Stock Company "ALROSA”, Udachny, Russia

\begin{abstract}
The study was focused on groundwaters sampled from boreholes drilled to deep horizons of the Udachnaya kimberlite pipe and the host sedimentary strata. Brines in the rocks significantly complicate underground mining. Analysis of the hydrogeological setting is required to ensure safety during mining to the design levels. The features of chemical composition and the geochemical evolution of brines in the crust can be clarified in a more detail on the basis of new reliable data on strong chloride saline solutions that formed in complex geological and tectonic conditions. Kimberlite and water samples were taken from the ore bodies and host sedimentary strata at the depth of 680-980 m. Conventional methods of quantitative and instrumental analysis were applied to study the chemical composition of brines. Mineral composition of kimberlite was determined by powder diffractography and X-ray fluorescence methods. Geological, structural and tectonophysical methods were used to reveal and describe the tectonic structure of the kimberlite pipe area. Groundwaters with salinity of 280-406 g/L are strong and very strong calcium chloride brines. The chlorine-bromine ratio has a small range of 48-57; the sodium-chlorine ratio varies from 0.11 to 0.18 . According to their geochemical features, the studied groundwaters are metamorphosed brines that have analogues across the Siberian platform. Physical and chemical processes were simulated to investigate the degrees of saturation of strong brines relative to the minerals of water-bearing rocks. The simulation results show that the brines in the Western ore body of the Udachnaya pipe are strongly undersaturated in the deep horizons in comparison to carbonate, sulfate and chloride minerals. This suggests possible dilution of brines during their geochemical evolution. A detailed study of the tectonic structure identified structural elements that control the distribution and migration of groundwaters in the rocks. In the mining sites, brines occur mainly in the fault zones, fault junctions and intersections with the contacts of kimberlite bodies. Integration of hydrogeological and geostructural data can provide a basis for prediction and assessment of the sites with increased water inflow in the deep horizons involved in mining.
\end{abstract}

Key words: chloride calcium brines; chemical composition of groundwater; brine salinity; fracturing; fault-block structure; ring-shaped faults; physical-chemical simulation; Udachnaya kimberlite pipe; underground mine

\section{RESEARCH ARTICLE}

Received: October 10, 2018

Статья подготовлена по материалам доклада, представленного на Всероссийском совещании по подземным водам Востока России (Новосибирск, 18-24 июня 2018 г.)

For citation: Alekseev S.V., Alekseeva L.P., Gladkov A.S., Trifonov N.S., Serebryakov E.V., Pavlov S.S., Il'in A.V., 2018. Brines in deep horizons of the Udachnaya kimberlite pipe. Geodynamics \& Tectonophysics 9 (4), 1235-1253. doi:10.5800/GT-2018-9-4-0393.

Для цитирования: Алексеев С.В., Алексеева Л.П., Гладков А.С., Трифонов Н.С., Серебряков Е.В., Павлов С.С., Ильин А.В. Рассолы глубоких горизонтов кимберлитовой трубки Удачная // Геодинамика и тектонофизика. 2018. Т. 9. № 4. C. 1235-1253. doi:10.5800/GT2018-9-4-0393. 


\title{
РАССОЛЫ ГЛУБОКИХ ГОРИЗОНТОВ КИМБЕРЛИТОВОЙ ТРУБКИ УДАЧНАЯ
}

\author{
С. В. Алексеев ${ }^{1}$, Л. П. Алексеева ${ }^{1,2}$, А. С. Гладков ${ }^{1}$, Н. С. Трифонов ${ }^{3,4}$, \\ Е. В. Серебряков ${ }^{1}$, С. С. Павлов ${ }^{5}$, А. В. Ильин ${ }^{6}$
}

\author{
${ }^{1}$ Институт земной коры СО РАН, Иркутск, Россия \\ ${ }^{2}$ Иркутский государственный университет, Иркутск, Россия \\ 3 Томский филиал Института нефтегазовой геологии и геофизики им. А.А. Трофимука СО РАН, \\ Томск, Россия \\ ${ }^{4}$ Национальный исследовательский Томский политехнический университет, Томск, Россия \\ 5 Удачнинский ГОК, АК «АЛРОСА» (ПАО), Удачный, Россия \\ ${ }^{6}$ Вилюйская ГРЭ АК «АЛРОСА» (ПАО), Удачный, Россия
}

\begin{abstract}
Аннотация: В работе представлены результаты изучения подземных вод, вскрытых скважинами в глубоких горизонтах кимберлитовой трубки Удачная и вмещающих осадочных толщах. Рассолы, обводняя горный массив, существенно осложняют проходку подземных горных выработок. Анализ гидрогеологической обстановки позволит обеспечить безопасную разработку месторождения до проектных отметок. Получение новых достоверных сведений о формировании крепких рассолов хлоридного состава в сложных геолого-тектонических условиях даст возможность объяснить многие особенности химического состава и геохимической эволюции рассолов в земной коре. Глубина отбора образцов кимберлитов и проб воды из рудных тел и вмещающих отложений составила 680-980 м. Химический состав рассолов проанализирован количественными традиционными и инструментальными методами, минеральный состав кимберлита определен методом порошковой дифрактографии и рентгенофлуоресцентным способом, тектоническое строение участка кимберлитовой трубки охарактеризовано с помощью геолого-структурных и тектонофизических методических приемов. Подземные воды с минерализацией 280-406 г/дм³ представляют собой крепкие и весьма крепкие рассолы хлоридного кальциевого состава. Величина хлорбромного отношения имеет небольшой диапазон (48-57), натрий-хлорный коэффициент изменяется от 0.11 до 0.18. Геохимические особенности изученных подземных вод позволяют отнести их к метаморфизованным рассолам, имеющим аналоги на всей Сибирской платформе. Физико-химическое моделирование степени насыщения крепких рассолов относительно минералов водовмещающих пород позволило установить, что рассолы западного рудного тела трубки Удачная в глубоких горизонтах по отношению к карбонатным, сульфатным и хлоридным минералам резко недонасыщены, что свидетельствует о возможном разбавлении рассолов в ходе их геохимической эволюции. Детальное изучение тектонического строения месторождения позволило выявить структурные элементы, контролирующие распределение и миграцию подземных вод в горном массиве. Основные проявления рассолов в горных выработках приурочены к зонам разрывных нарушений, их узлам и участкам пересечения с контактами кимберлитовых тел. Комплексирование гидрогеологических и геолого-структурных данных может служить основой для прогнозной оценки участков повышенных водопритоков в глубоких горизонтах, вовлекаемых в эксплуатацию.
\end{abstract}

Ключевые слова: хлоридные кальциевые рассолы; химический состав подземных вод; минерализация рассолов; трещиноватость; разломно-блоковое строение; кольцевые разрывные нарушения; физико-химическое моделирование; кимберлитовая трубка Удачная; подземный рудник

\section{1. ВВЕДЕНИЕ}

Кимберлитовая трубка Удачная $\left(112^{\circ} 18^{\prime} 16^{\prime \prime}-\right.$

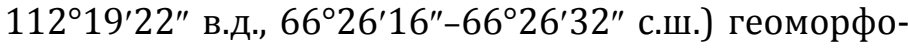
логически расположена на левом берегу ручья Пиропового - правого притока р. Далдын (приток p. Марха, которая впадает в р. Вилюй). Это крупнейшее по размерам рудного тела месторождение алмазов в России находится в 20 км от Северного полярного круга в Якутской алмазоносной провинции. Открытая разработка алмазоносной трубки Удачная осуществлялась с 1971 г. до июня 2014 г., глубина карьера достигла 640 м, а в настоящее время добыча алмазов продолжается подземным способом.

Как в карьере, так и в подземном руднике отработка месторождения осложнена притоком хлоридных подземных рассолов в шахту на глубине свыше 700 м (-365...-465 м абс.). Необходимость изучения такого типа подземных вод связана с их особыми свойствами.

Прежде всего высокоминерализованные газонасыщенные подземные воды снижают прочностные характеристики горного массива, вызывают ак- 
тивную коррозию проходческого и насосного оборудования, содержат потенциально взрывоопасные гомологи метана и резко осложняют проходку подземных горных выработок. Получение и анализ оперативных данных позволят обеспечить безопасную разработку месторождения до проектных отметок. Кроме того, проблема генезиса и особенностей формирования крепких рассолов хлоридного состава является предметом дискуссии в фундаментальной науке уже не одно десятилетие. В этой связи получение новых достоверных результатов на основе использования современных аналитических и изотопных методов исследований даст возможность объяснить многие особенности химического состава и геохимической эволюции рассолов в земной коре.

Цель настоящей работы - дать комплексную характеристику геолого-тектонических и гидрогеологических условий глубоких горизонтов кимберлитовой трубки Удачная, которые оказывают непосредственное влияние на отработку месторождения подземным способом.

\section{2. МАТЕРИАЛЫ И МЕТОДЫ ИССЛЕДОВАНИЯ}

В июле - августе 2017 г. на промплощадке Удачнинского ГОКа АК «АЛРОСА» выполнено гидрохимическое опробование скважин, пробуренных в глубоких горизонтах кимберлитовой трубки Удачная. Отобраны пробы рассолов в западном (ЗРТ) и восточном (ВРТ) рудных телах (горизонт -465 м абс., две скважины), а также во вмещающих осадочных толщах среднего кембрия (горизонт -365 м абс., шесть скважин - по три соответственно на флангах ЗРТ и ВРТ). Глубина скважин составила 100-314 м. Химический состав рассолов проанализирован в ЦКП «Геодинамика и геохронология» (ИЗК СО РАН, г. Иркутск) на основе количественных инструментальных методов: концентрация $\mathrm{K}^{+}$, $\mathrm{Na}^{+}, \mathrm{Li}^{+}, \mathrm{Rb}^{+}, \mathrm{Cs}^{+}, \mathrm{Sr}^{2+}$ - методом пламенной фотометрии на атомно-абсорбционном спектрофотометре SOLAAR M (Thermo Elemental, IN-TERTECH Corporation, США), содержание анионов (а также $\mathrm{Ca}^{2+}, \mathrm{Mg}^{2+}$ ) - титриметрическим методом, концентрация $\mathrm{SO}_{4}^{2-}$ - весовым методом.

Для определения минерального состава образцы проб кимберлита, истертые в агатовой ступке со спиртом, исследованы методом порошковой дифракции на рентгеновском дифрактометре D8 Advance (Bruker AXS, Германия) с радиусом гониометра - 250 мм. Условия измерения: излучение $\mathrm{CuK} \alpha, \mathrm{V}=40$ кB, I=40 мA, зеркало Гёбеля, щели Соллера - 2.5 мм, сцинтилляционный счётчик, угловой диапазон: $3-65^{\circ} 2 \theta$, шаг сканирования - $0.02^{\circ}$, экспозиция - 1 с/шаг. Съемка некоторых проб прово- дилась на дифрактометре ДРОН - 3.0, излучение $\mathrm{CuK} \alpha, \mathrm{Ni}$ - фильтр, V= 25 кB, I=20 мА, в диапазоне 3 $65^{\circ} 2 \theta$, шаг сканирования - 0.05․ Фазовый состав проб расшифрован с помощью программы EVA (Diffracplus, PDF-2, 2007 г.). Приведены данные полуколичественного анализа определенных фаз в пробах, расчеты проведены методом RIR по корундовым числам минеральных фаз из кристаллографической базы данных PDF-2 [Hubbard, Snyder, 1988].

Для уточнения минерального состава проведено рентгенофлуоресцентное определение содержаний основных и примесных элементов в 45 образцах. Определение выполнено на кристалл-дифракционном спектрометре S4 Pioneer фирмы Bruker Nano $\mathrm{GmbH}$ (Германия). Излучатели подготовлены на подложке из борной кислоты с помощью полуавтоматического гидравлического пресса HERZOG НТР-40 с усилием 100 кН в течение 5 с.

Дополнительно проведена идентификация фаз глинистых минералов: подготовка ориентированного материала пробы выполнена осаждением глинистой фракции на стеклянной подложке, прогреванием при температуре $550{ }^{\circ} \mathrm{C}$ в течение 3 час и насыщением этиленгликолем и диметилсульфоксидом [Brown, 1961].

Для характеристики тектонического строения участка локализации трубки Удачная использовались полевые геолого-структурные и тектонофизические методические приемы, направленные на изучение тектонической трещиноватости, а также зон разломов, картирование основных элементов их внутреннего строения и восстановление полей тектонических напряжений. С этой целью на горизонтах $-320 \ldots-580$ м абс. была создана сеть из 348 точек, в пределах которых проводился комплекс однотипных измерений. Наблюдения проводились в стенках и забоях горных выработок рудника.

Методика наблюдений подробно изложена в работе [Gladkov et al., 2008]. После привязки точки на плане горизонта проводилось детальное изучение трещинной сети и разрывных нарушений различного ранга. В каждой точке наблюдения выделялись основные системы тектонических трещин, измерялись их элементы залегания, устанавливался генетический тип трещин, слагающих систему, а также описывались особенности взаимоотношения систем различных направлений. Далее определялись такие характеристики трещинной сети, как количество трещин на пог. м (густота трещин - Гі),

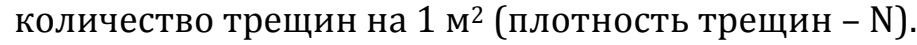

Наиболее масштабные дизъюнктивные структуры, которые были задокументированы при проведении полевых работ, - это разрывные нарушения, представленные зонами повышенной трещиноватости, дробления, брекчирования и рассланцева- 
ния мощностью от нескольких сантиметров до десяти метров и более и длиной в десятки - сотни метров. Для них, помимо элементов залегания, определялись видимая мощность, амплитуда смещения, особенности вещественного и структурного заполнения, тип контактов с вмещающей толщей и пр.

В точках, где позволяли условия безопасного проведения работ (26 точек), выполнялся массовый замер элементов залегания 75-100 трещин в пределах произвольно выбранной документируемой площадки с обязательным указанием их генетической разновидности (сколовая или отрывная). Особое внимание при замерах уделялось выявлению трещин, которые возникли в процессе проведения взрывных работ и по этой причине в массовый замер не включались. В случае наличия зеркал скольжения и признаков перемещения блоков горных пород по поверхности трещин документировались ориентировки штрихов (или борозд), давалось описание самой поверхности скольжения (морфология, распределение заполнителя по плоскости и т.д.), а также определялся (если это было возможно) знак смещения. Кроме дизъюнктивных структур, на точке наблюдения описывались (в случае их наличия) другие структурные формы: складки, будины, линейность и т.д.

Полученная информация сводилась в табличную форму. Для дальнейшей ее обработки и анализа использовались как известные программные продукты (SURFER, RockWorks15), так и оригинальная разработка лаборатории тектонофизики - программный комплекс STRUCTURE. Последний предназначен для построения, обработки и анализа структурных диаграмм по замерам трещин и разрывных нарушений. Для визуализации и определения особенностей пространственного распределения дизъюнктивных структур были построены объемные схемы распределения наиболее густых систем трещин, зон разрывных нарушений, зафиксированных малых дайковых тел и пр.

Эти материалы послужили фактологической основой для построения объемной схемы разломного строения и анализа особенностей тектонической структуры участка локализации трубки Удачная, результаты которого приведены в последующих разделах статьи.

\section{3. ГЕОЛОГИЧЕСКОЕ И ТЕКТОНИЧЕСКОЕ СТРОЕНИЕ ТРУБКИ У ДАЧНАЯ}

Кимберлитовая трубка Удачная находится в зоне сочленения крупных тектонических структур - Анабарской антеклизы и Тунгусской синеклизы, характеризующихся широким распространением терригенно-карбонатных отложений нижнепалеозойского возраста (рис. 1).

Основную часть разреза слагают пористо-кавернозные доломиты и известняки нижнего кембрия верхнего ордовика, содержащие прослои известковистых алевролитов, мергелей, песчаников, реже конгломератов, гравелитов и карбонатных брекчий. Для пород характерно неравномерное содержание нефти и битума. В верхних частях разреза отдельные свиты обильно насыщенны углеводородами, в то время как с глубиной их содержание резко уменьшается. Так же неравномерно по разрезу распределены проявления палеокарста и каверн, которые обнаруживаются в пределах известководоломитовых толщ в виде разнообразных по форме полостей размером от нескольких сантиметров до первых десятков метров, пустых либо заполненных брекчиями обрушения или рассолами. Они чаще всего приурочены к зонам повышенной тектонической трещиноватости и в максимальном количестве наблюдаются в области экзоконтакта с кимберлитовым телом. Поры и каверны нередко выполнены вторичными низкотемпературными минералами, такими как кварц, барит, кальцит.

Магматические образования в пределах месторождения представлены кимберлитами щелочноультраосновной формации, в которую входят дорудные и внутрирудные жилы, а также собственно тело кимберлитовой трубки. Первые из них представлены мелкими телами мощностью от 5 до 40 см, с редкими раздувами до 2.5 м, прослеженными на расстояние до 800 м от современного контура трубки. Большая их часть приурочена к зоне разрывных нарушений северо-восточной ориентировки, однако встречаются единичные жилы, простирающиеся в северо-западном направлении. Они прослежены как на верхних горизонтах в бортах карьера трубки, так и на нижних (отметки $-380 .$. -480 м абс.) в стенках горных выработок подземного рудника.

Основной объем руды сосредоточен в паре сближенных обособленных диатрем: Удачная-Западная и Удачная-Восточная. Начиная с отметки 270 м и до поверхности указанные трубки образуют единое тело размером 895×(560-370) м [Kostrovitsky et al., 2015]. Ниже они разделены сильно деформированной перемычкой осадочных пород, имеющей клавишное грабенообразное строение с максимальной сбросовой амплитудой смещения по разломам около 140 м. С глубиной расстояние между диатремами заметно возрастает вследствие падения контактов тел к центрам. Так, на глубине -480 м абс. оно составляет 193, а на глубине -1080 м абс. $325 \mathrm{M}$.

Западное рудное тело (Удачная-Западная) на верхних горизонтах имеет эллипсовидную в плане 

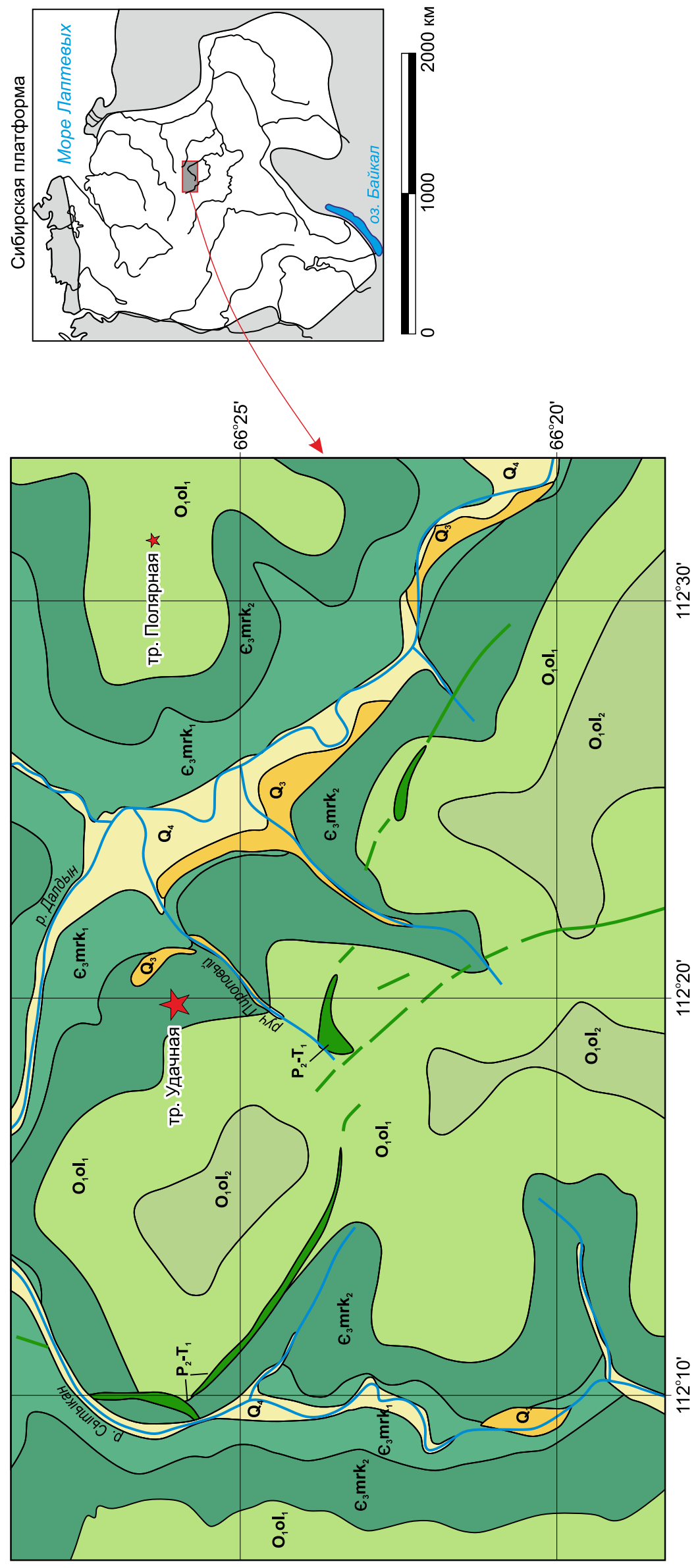

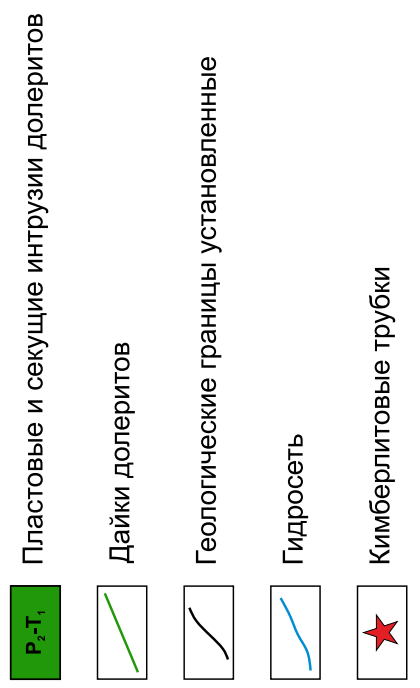

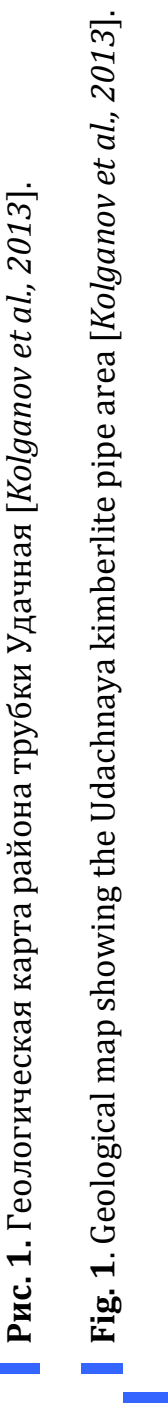


форму, вытянутую в северо-западном направлении, которая на более глубоких горизонтах трансформируется в почти изометричную. Размеры тела на уровне -580 м абс. составляют $245 \times 195$ м, а на горизонте -1080 м абс. сокращаются до 110×110 м. Контакты рудного тела с вмещающими породами в основном «рвущие», резкие, реже - «плавающие», наблюдаемые в зоне ближнего экзоконтакта. Углы падения варьируются в широких пределах - от $60^{\circ}$ до субвертикальных. На глубине ниже горизонта -880 м абс. в границах кимберлитовой трубки вскрыт массив осадочных пород с ненарушенным залеганием и первичной текстурой, что свидетельствует о разделении Западного рудного тела на два обособленных подводящих канала [Kostrovitsky et al., 2015].

Вещественный состав Удачной-Западной представлен типичным для трубок Якутской алмазоносной провинции комплексом образований: порфировый кимберлит ранних генераций и автолитовая кимберлитовая брекчия заключительных стадий магматизма. В пределах тела присутствует большое количество крупных ксенолитов осадочных пород, к которым приурочены нефте- и битумопроявления. В целом Западное рудное тело в значительной степени осложнено тектоническими зонами дробления и трещиноватости, наличием в них рассолов, водорастворенных и свободных газов [Kolganov et al., 2013; Kostrovitsky et al., 2015].

Восточное рудное тело (Удачная-Восточная) в горизонтальном сечении имеет эллипсовидную форму, слегка вытянутую в северо-восточном направлении, которую оно сохраняет до глубоких горизонтов. Размеры диатремы несколько больше, чем размеры трубки Удачная-Западная, и составляют на горизонте -480 м абс. $280 \times 245$ м, а на горизонте -1080 м абс. - 280×190 м. Контакты с вмещающими толщами четкие, большей частью субвертикальные, что выражается в относительно небольшом уменьшении площади поперечного сечения трубки до глубины 1300-1400 м.

Трубка сложена двумя рудными генерациями: основную массу составляет автолитовая брекчия, в подчиненном значении находится порфировый кимберлит. Последний, наряду с ксенолитами вмещающих пород, наблюдается в пределах рудного тела в виде различных по размеру обломков. В отличие от Западного рудного тела, Восточное менее нарушено дизъюнктивными элементами, а наибольшее количество зон трещиноватости находится в области эндоконтакта.

Внутрирудные жилы представляют собой наиболее поздние проявления кимберлитового магматизма в пределах месторождения и образуют небольшие по размерам тела сложной формы, расположенные в границах обеих диатрем трубки.
Основу структуры месторождения составляют две системы дизъюнктивов: первая - северо-восточного простирания (70-80), ограничивающая трубку Удачная-Западная с юго-востока и имеющая сквозное положение по отношению к трубке Удачная-Восточная; вторая - северо-западного простирания (305-315), ограничивающая трубку Удачная-Западная с северо-востока (рис. 2).

Указанные разломы не имеют четко выраженного сместителя, а представляют зоны сгущения (в 3-5 раз), по сравнению с сопредельными участками, трещин конкретного направления. Они контролируются глубинными региональными разрывами, прослеженными геофизическими методами в фундаменте и низах осадочного чехла территории. Помимо них осложняющими элементами являются локальные нарушения субширотного и субмеридионального направления.

Разрывы северо-восточной ориентировки являются кимберлитовмещающими для месторождения, на что указывает вытянутость длинной оси трубки в северо-восточном направлении, а также приуроченность большей части кимберлитовых жил к дизъюнктивам этой системы.

Наиболее густая сеть нарушений северо-восточной ориентировки зафиксирована в выработках, пройденных по межтрубью на горизонтах $-480 .$. -320 м абс. Дизъюнктивы здесь представлены зонами повышенной трещиноватости и дробления небольшой мощности (порядка 0.5-1.5 м). Расстояние между ними в местах сгущения составляет не более 5-10 м, что позволяет группировать их в единые зоны. По некоторым зонам наблюдается обильный водоприток в виде сосредоточенной разгрузки подземных вод и интенсивного капежа. Довольно густая сеть нарушений, большая часть которых приурочена к области экзоконтакта, зафиксирована и по северному контуру трубки, на горизонтах -320 и -360 м абс.

Система нарушений северо-западного простирания в пределах месторождения представлена зоной, имеющей азимут простирания 305-315, угол падения 80-88 и мощность около 150 м. Одним из наиболее крупных ее элементов является Октябрьский разлом, установленный по результатам геофизических исследований и выраженный дайкой траппов мощностью более 50 м, протягивающейся по осевой линии нарушения. Этот дизъюнктив использовался для захоронения дренажных рассолов карьера трубки Удачной [Alekseev et al., 2000; Alekseev, 2009; Kolganov et al., 2013].

Отдельные сместители рассматриваемой системы выполнены брекчией карбонатных пород, иногда с плоскостями скольжения и глинкой трения, по которым отмечается интенсивное ожелезнение. Вниз по разрезу интенсивность проявления дизъ- 


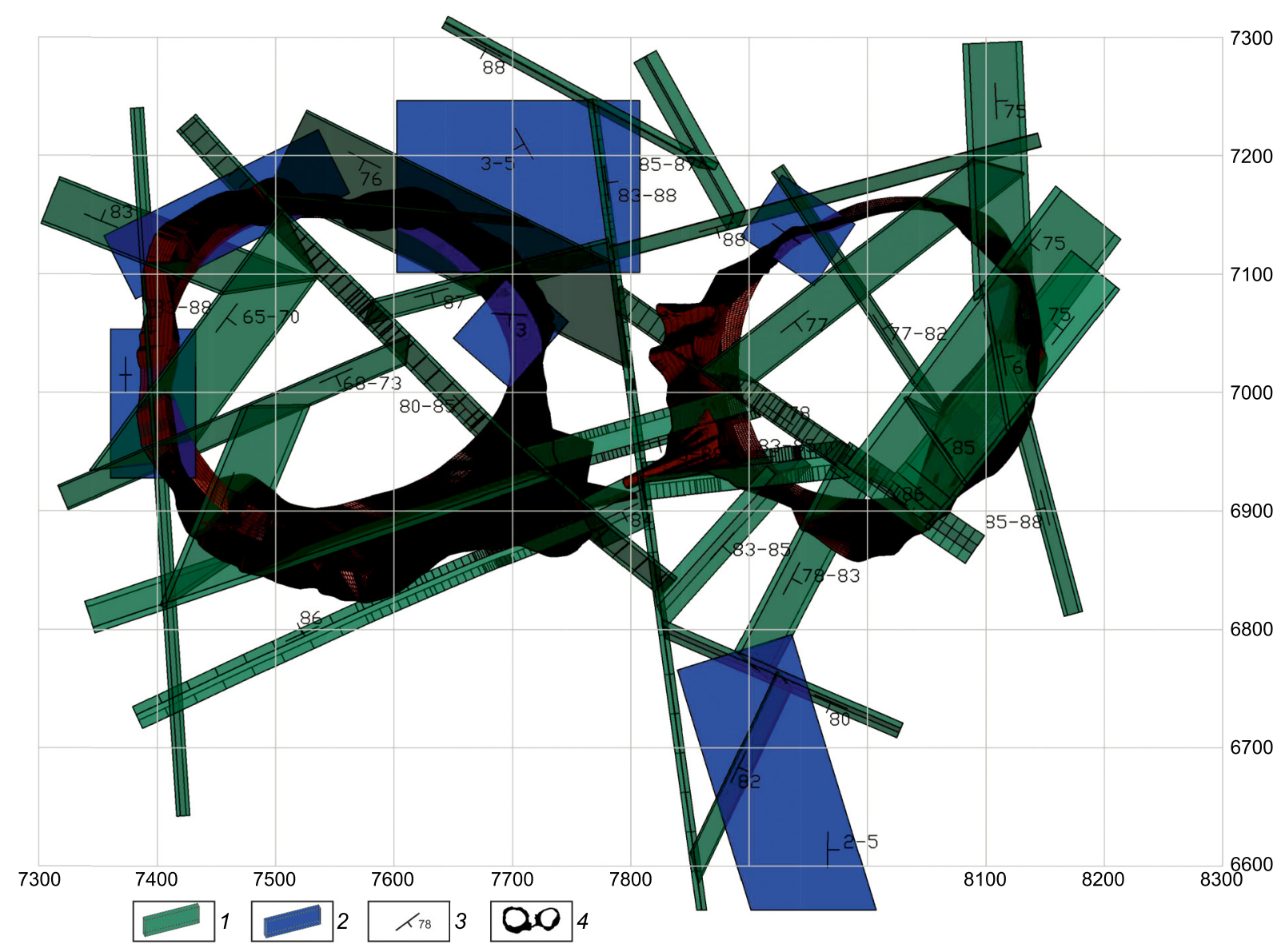

Рис. 2. Объемная схема разломно-блокового строения участка локализации кимберлитовой трубки Удачная (вид сверху). 1 - субвертикальные разрывные нарушения; 2 - субгоризонтальные разрывные нарушения; 3 - элементы залегания разрывных нарушений; 4 - контакты кимберлитовых тел.

Fig. 2. 3D scheme showing the fault-block structure of the Udachnaya kimberlite pipe area (top view). 1 - subvertical faults; 2 - subhorizontal faults; 3 - fault dip and strike; 4 - contacts of kimberlite bodies.

юнктивов снижается. На горизонтах глубже -320 м абс. нарушения представляют собой области сгущения крупных сколов либо небольшие зоны трещиноватости и дробления без видимых следов перемещения крыльев разлома. Для разрывов северозападной ориентировки характерна выдержанность элементов залегания и мощности зон. На некоторых участках выделенные зоны трассируются с горизонта на горизонт (около 100 м в вертикальной проекции) без существенного изменения параметров, образуя единые сместители. Такие зоны, как правило, представлены субвертикальными крупными трещинами сколовой или отрывной природы, с зиянием до 0.3-0.4 м. Они являются путями миграции рассолов, что выражается в значительном водопритоке из них.

Системы субширотных и субмеридиональных нарушений имеют подчиненное значение в общей тектонической структуре месторождения. Парагенетически они относятся к числу оперяющих разрывов для ранее рассмотренных крупных разлом- ных зон северо-восточной и северо-западной ориентировки. Они проявляются в виде маломощных зон повышенной трещиноватости, реже - брекчирования, с пониженными показателями густоты и плотности трещин, слагающих эти зоны.

Помимо линейных дизъюнктивов в строении трубки Удачная значительную роль играют кольцевые разрывы, которые особенно отчетливо проявлены на верхних горизонтах (рис. 3).

В их системе выделяется три зоны: внутренняя, промежуточная и внешняя [Kolganov et al., 2013]. Внутренняя зона выражена серией кольцевых сбросов и сдвигов и протягивается параллельно контурам трубок на расстояние до 80 м. В отметках $-280 \ldots-350$ м абс. детально задокументирована кольцевая система наклонных дизъюнктивов, падающих к центрам рудных тел, которая опоясывает трубку и имеет вид усеченного конуса, проникая из вмещающих пород по зонам экзо- и эндоконтакта в рудное тело. Она прослежена в виде единой замкнутой структуры вокруг большей части запад- 


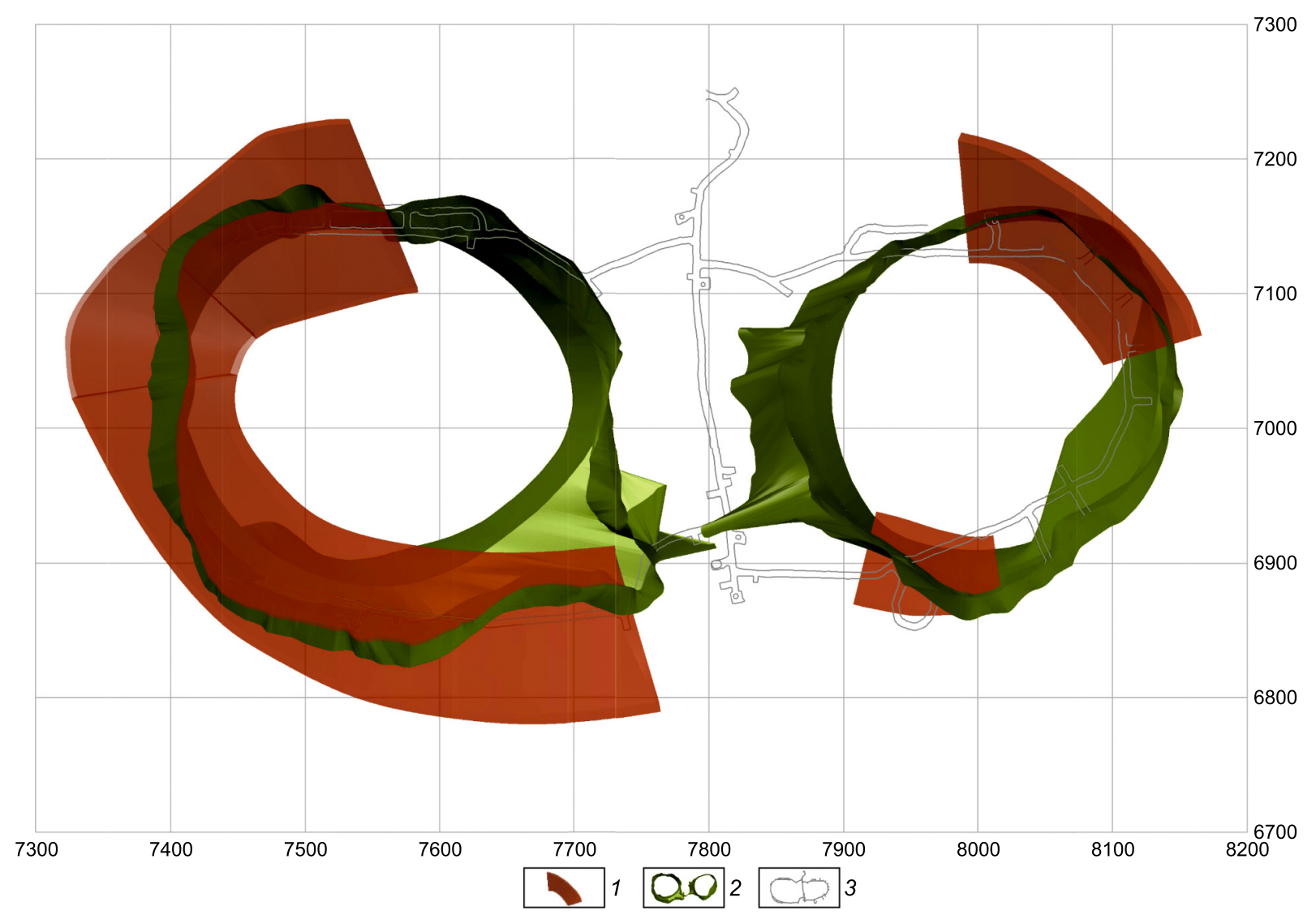

Рис. 3. Схема кольцевых наклонных нарушений по периферии кимберлитовых тел трубки Удачная. 1 - кольцевые разрывные нарушения; 2 - контакты кимберлитовых тел; 3 - контуры горных выработок на горизонте -320 м абс.

Fig. 3. Schematic map showing ring-shaped inclined faults at the periphery of the kimberlite bodies of the Udachnaya pipe. 1 - ring-shaped faults; 2 - contacts of kimberlite bodies; 3 - contours of mine workings (horizon - $320 \mathrm{~m}$ asl).

ного рудного тела и фрагментарно - вокруг восточного. Промежуточная и внешняя зоны в общих чертах повторяют контуры внутренней и располагаются от последней на расстоянии 40-100 м и 250-350 м соответственно.

\section{4. ГИДРОГЕОЛОГИЧЕСКИЕ УСЛОВИЯ}

Согласно гидрогеологическому районированию Восточно-Сибирской артезианской области, трубка Удачная находится в пределах Оленекского криоартезианского бассейна в северо-восточной части Сибирской платформы [Melnikov, 1984]. В геокриологическом отношении регион относится к области сплошного распространения многолетнемерзлых пород с криолитозоной уникальной мощности (более 1400 м) и низкой отрицательной температурой пород (до $-7.8{ }^{\circ} \mathrm{C}$ на подошве слоя годовых теплооборотов). Особенностью гидрогеологического разреза является наличие межмерзлотных и подмерзлотных криопэгов хлоридного кальциевого состава с минерализацией до 425 г/дм³ ${ }^{3}$ залегающих на глубине 110-1000 м [Alekseev, 2009].
Гидрогеологический разрез Оленекского бассейна формируют подземные воды верхне-, средне-, нижнекембрийского и протерозойского водоносных комплексов, а также обводненных зон кимберлитовых трубок и трапповых интрузий (рис. 4).

Подземные воды верхнекембрийского комплекса $\left(\epsilon_{3}\right)$ входят в первую гидрохимическую зону соленых вод, слабых и крепких рассолов. Их минерализация изменяется в широких пределах - от 31 до 200 г/дм³ ${ }^{3}$ Среди катионов преобладают либо кальций, либо магний. Доля натрия достаточно высокая (11-30 \%-экв.), иногда больше содержания магния, что отражается в названии типа рассолов - они становятся натриево-кальциевыми. Анионный состав исключительно хлоридный, содержание сульфат- и гидрокарбонат-иона незначительное и в среднем составляет 0.98 и 0.12 г/дм ${ }^{3}$ соответственно.

Подземные воды нижне- и среднекембрийских водоносных комплексов $\left(\epsilon_{1}, \epsilon_{2}\right)$ формируют вторую гидрохимическую зону крепких и весьма крепких рассолов. Минерализация рассолов изменяется от 207 до 406 г/дм³ ${ }^{3}$ Ведущим анионом является хлор, среди катионов доминирует кальций. Содержание натрия, магния и калия находится в соотношении 
3

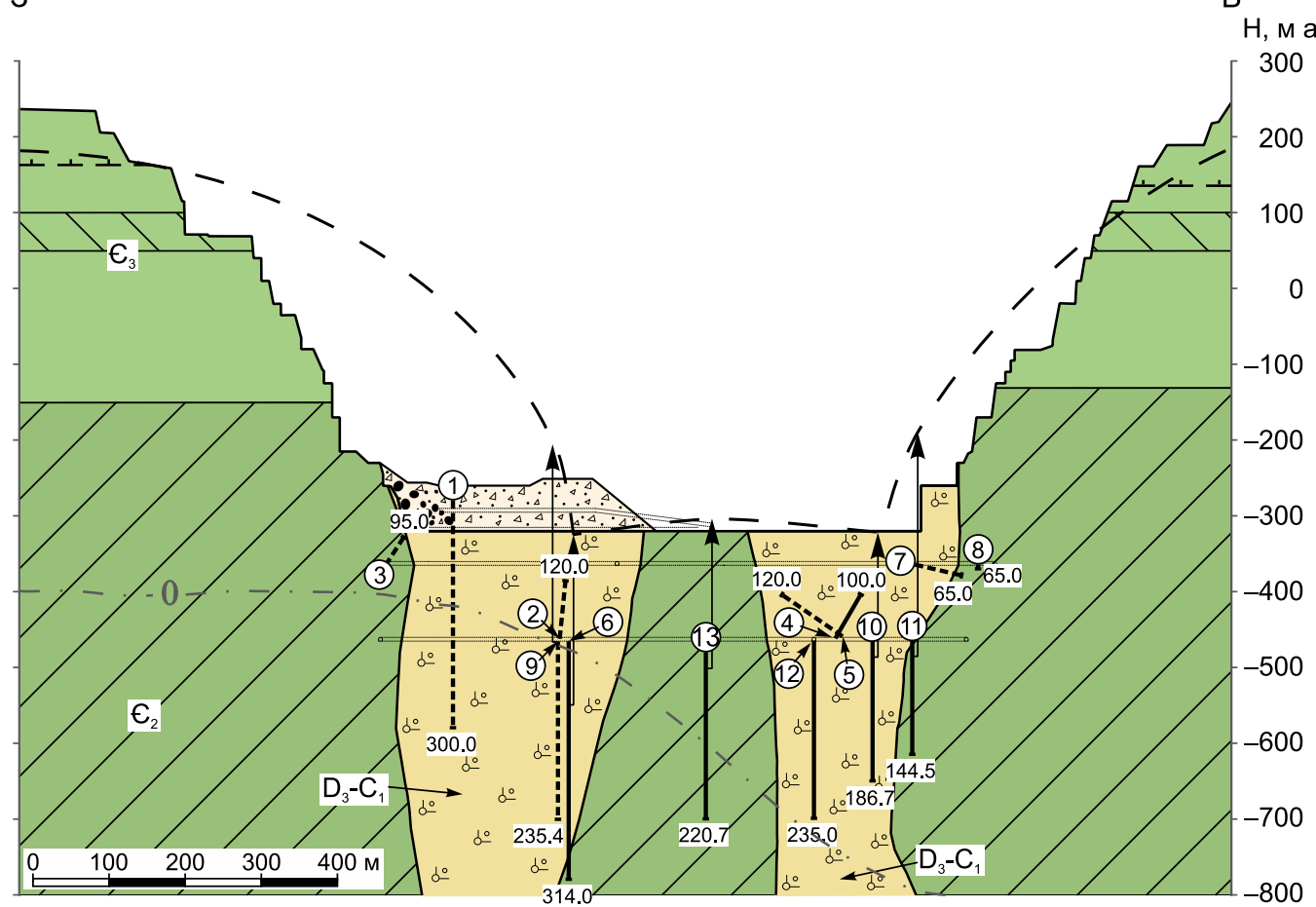

$-800$
Литология осадочных

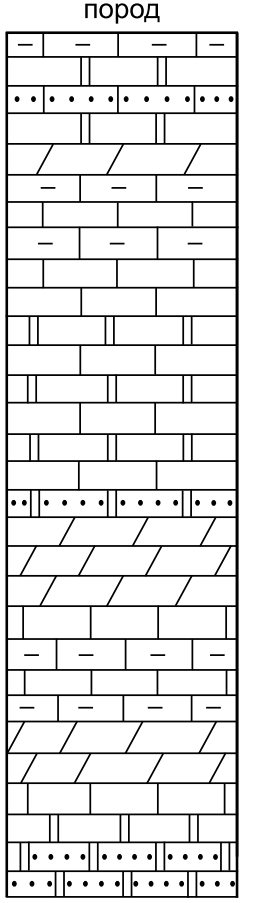

$\triangle \nabla_{1} \nearrow^{2}$

$\therefore 3$

$--74$

$\leftrightarrow 5$
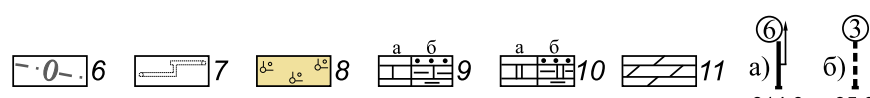

(3)

а)

Рис. 4. Схематический мерзлотно-гидрогеологический разрез кимберлитовой трубки Удачная.

1 - подмерзлотный верхнекембрийский водоносный комплекс соленых вод и слабых рассолов; 2 - подмерзлотный среднекембрийский водоносный комплекс крепких и весьма крепких рассолов (область без штриховки - водоупор); 3 - предохранительная «подушка» из руды и вмещающих пород; 4 - пьезометрический уровень среднекембрийского водоносного комплекса и второй обводненной зоны трубки Удачная; 5 - подошва многолетнемерзлых пород; 6 - нулевая изотерма, ${ }^{\circ} \mathrm{C} ; 7$ - горные выработки; 8 - кимберлитовая трубка; 9 - известняки (а) и известняки песчанистые и глинистые (б); 10 - доломиты (а) и доломиты песчанистые и глинистые (б); 11 - мергели; 12 - скважина: вертикальная (а), проекция наклонной скважины (б), цифры: внизу - глубина, м, вверху в кружке - условный номер скважины $(1$ - скв. 04/45, 2 - скв. ДС-1.2, 3 - скв. ДС-5.4, 4 - скв. ДС-8.2в, 5 - скв. ДС-8.3в, 6 - скв. СГК-1, 7 - скв. КДС-3, 8 - скв. КДС-4, 9 - скв. СРП-2, 10 - скв. СРП-3, 11 - скв. СРП-4, 12 - скв. СРП-5, 13 - скв. СРП-6), стрелка - напор над кровлей вскрытой обводненной зоны, водоносного комплекса (горизонта).

Fig. 4. Schematic permafrost-hydrogeological section of the Udachnaya kimberlite pipe.

1 - Upper Cambrian sub-permafrost aquifer (saline waters and low-concentration brines); 2 - Middle Cambrian sub-permafrost aquifer (strong and very strong brines) (area without hatching - aquitard); 3 - safety 'cushion' of ore and host rocks; 4 - piezometric level of the Middle Cambrian aquifer and the second water-saturated zone of the Udachnaya pipe; 5 - permafrost base; $6-$ zero isotherm, ${ }^{\circ} \mathrm{C}$; 7 - excavations; 8 - kimberlite pipe; 9 - limestone (a) and sandy and clayey limestone (б); 10 - dolomite (a) and sandy and clayey dolomite (б), 11 - marls; 12 - borehole: vertical (a), projection of the inclined borehole (б), numbers at the bottom - depth, m, numbers at the top (in circles) - borehole number (1 - borehole 04/45; 2 - ДС-1.2; 3 - ДС-5.4; 4 - ДС-8.2в; 5 - ДС-8.3в; 6 - СГК-1; 7 - КДС-3; 8 КДС-4; 9 - СРП-2; 10 - СРП-3; 11 - СРП-4; 12 - СРП-5; 13 - СРП-6), arrow - pressure over the top of the drilled water-saturated zone, aquifer.

$\mathrm{Na}>\mathrm{Mg} \geq \mathrm{K}$, причем максимальные абсолютные значения этих катионов не превышают $25 \%$-экв. Хлорбромное отношение $\mathrm{Cl} / \mathrm{Br}$ составляет 27-73, натрий-хлорное $\mathrm{rNa} / \mathrm{rCl}$ не превышает 0.3 , величина $\mathrm{pH}$ составляет 2.8-7.1.

В гидрогеологическом разрезе трубки Удачная выделены две обводненные зоны, которые изучены достаточно детально до глубины 750 м (-380 м абс.).

Первая от поверхности приурочена к подошве зоны экзогенной трещиноватости кимберлитов и вскрыта на отметке $+100 \ldots+144$ м абс. в западном рудном теле и $+100 \ldots+152$ м абс. - в восточном. Пьезометрический уровень подземных вод в рудных телах аналогичен уровню подземных вод верхнекембрийского водоносного комплекса. Коэффициент водопроводимости изменяется в широком

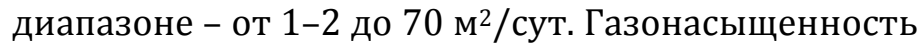
рассолов достигает $0.2 \mathrm{~m}^{3} / \mathrm{m}^{3}$. В ходе разработки месторождения открытым способом первая обводненная зона осушена.

Рассолы второй зоны в рудных телах вскрыты в интервале глубин 350-960 м. Кимберлиты харак- 
Т а б л и ц а 1 Х.Химческий состав подземных рассолов глубоких горизонтов трубки Удачная

$\mathrm{T}$ a b l e 1. The chemical composition of ground brines in deep horizons of the Udachnaya pipe

\begin{tabular}{|c|c|c|c|c|c|c|c|c|c|c|c|c|c|}
\hline \multirow[t]{2}{*}{ №* пробы } & \multirow{2}{*}{ 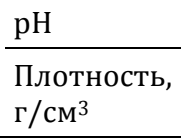 } & \multicolumn{8}{|c|}{ Ионный состав, г/дм³ } & \multicolumn{3}{|c|}{ Микрокомпоненты, мг/дм³ } & \multirow[t]{2}{*}{$\mathrm{M}, \Gamma / д \mathrm{M}^{3}$} \\
\hline & & $\mathrm{K}^{+}$ & $\mathrm{Na}^{+}$ & $\mathrm{Mg}^{2+}$ & $\mathrm{Ca}^{2+}$ & $\mathrm{Cl}^{-}$ & $\mathrm{Br}^{-}$ & $\mathrm{SO}_{4}^{2-}$ & $\mathrm{HCO}^{3-}$ & $\mathrm{Li}^{+}$ & $\mathrm{Rb}^{+}$ & $\mathrm{Sr}^{2+}$ & \\
\hline 1 & $\begin{array}{l}4.65 \\
1.287\end{array}$ & 18.2 & 18.4 & 15.9 & 92.2 & 256.2 & 5.3 & 0.02 & 0.2 & 290.5 & 16.0 & 1866.7 & 406.3 \\
\hline 2 & $\begin{array}{l}4.85 \\
1.272\end{array}$ & 15.8 & 24.9 & 14.8 & 81.4 & 244.4 & 4.3 & 0.05 & 0.1 & 234.6 & 7.6 & 1414.5 & 385.8 \\
\hline 3 & $\begin{array}{l}4.57 \\
1.267\end{array}$ & 14.4 & 26.9 & 14.1 & 79.2 & 238.5 & 4.4 & 0.08 & 0.1 & 222.2 & 6.9 & 1290.2 & 377.8 \\
\hline 4 & $\begin{array}{l}4.9 \\
1.274\end{array}$ & 15.0 & 23.8 & 14.9 & 81.5 & 244.4 & 4.5 & 0.04 & 0.1 & 236.7 & 5.9 & 1581.9 & 384.2 \\
\hline $5 \mathrm{BPT}$ & $\begin{array}{l}5.80 \\
1.208\end{array}$ & 11.3 & 20.5 & 10.6 & 61.1 & 180.0 & 3.4 & 0.18 & 0.2 & 171.4 & 7.8 & 1057.8 & 287.4 \\
\hline 6 ЗРТ & $\begin{array}{l}4.75 \\
1.287\end{array}$ & 18.6 & 18.4 & 15.1 & 92.6 & 251.4 & 5.1 & 0.03 & 0.3 & 293.3 & 15.3 & 2206.2 & 401.5 \\
\hline 7 & $\begin{array}{l}4.8 \\
1.277\end{array}$ & 16.9 & 21.1 & 16.9 & 85.8 & 248.5 & 4.7 & 0.05 & 0.2 & 260.3 & 12.4 & 1453.9 & 394.1 \\
\hline 8 & $\begin{array}{l}4.77 \\
1.259 \\
\end{array}$ & 14.1 & 24.0 & 14.9 & 77.3 & 234.7 & 4.3 & 0.06 & 0.1 & 219.7 & 7.5 & 1325.4 & 369.3 \\
\hline
\end{tabular}

П р и м е ч а н и е. * - номера проб соответствуют условным номерам скважин на разрезе; жирный шрифт (1, 2, 3) - скважины, пробуренные во вмещающих породах на флангах ВРТ, курсив $(4,7,8)$ - скважины, пробуренные во вмещающих породах на флангах 3РТ; 5 и 6 - скважины, пробуренные в рудных телах. М - минерализация воды.

$\mathrm{N}$ o t e. ${ }^{*}$ - sample numbers correspond to the reference numbers of borehole in the section; bold numbers $(\mathbf{1}, \mathbf{2}, \mathbf{3})-$ boreholes in host rocks at the flanks of the Eastern ore body (BPT), italics $(4,7,8)$ - boreholes in host rocks at the flanks of the Western ore body $(3 \mathrm{PT}) ; 5$ and 6 - boreholes in ore bodies. M - water salinity.

теризуются различной водообильностью и большим разбросом значений коэффициента водопроводимости - 2.0 в ЗРТ и $20 \mathrm{~m}^{2} /$ сут в ВРТ. Дебит скважин, пробуренных с горизонтов -365 и -465 м абс., изменяется от 0.06-9.00 (ЗРТ, вмещающие породы) до 60-78 м³/час (ВРТ, вмещающие породы). Температура рассолов варьируется от -2.0 до $+3.0{ }^{\circ} \mathrm{C}$. Газонасыщенность подземных вод составляет 0.0001-0.0300 $\mathrm{m}^{3} / \mathrm{M}^{3}$.

Новые полученные данные (табл. 1) показывают, что в рассолах, вскрытых в рудных телах трубки Удачная и во вмещающих осадочных толщах, ведущим анионом является хлор. Его концентрация изменяется в диапазоне 180-256 г/дм³ ${ }^{3}$. Среднее содержание сульфат- и гидрокарбонат-иона составляет 0.065 и 0.155 г/дм ${ }^{3}$ соответственно. Концентрация брома изменяется от 3.4 до 5.3 г/дм³ ${ }^{3}$. Среди катионов доминирует кальций с максимальным содержанием 92.6 г/дм³. При анализе корреляционной матрицы установлена тесная взаимосвязь ионов натрия, магния, кальция, хлора и минерализации подземных вод. Хлорбромное отношение имеет небольшой разброс (48-57). Величина натрий-хлорного отношения колеблется в пределах 0.11-0.18. Содержание микрокомпонентов $\left(\mathrm{Li}^{+}, \mathrm{Rb}^{+}, \mathrm{Sr}^{2+}\right)$ высокое, что характерно для метаморфизованных седиментационных вод.

Подземные воды, вскрытые в рудных телах, гидравлически связаны с водоносными комплексами вмещающих осадочных горных пород. Они в целом идентичны по составу и минерализации.

На настоящем этапе установлено, что все отобранные пробы воды геохимически едины, т.е. воды хлоридные кальциевые, по минерализации и величине $\mathrm{pH}$ - крепкие и весьма крепкие кислые рассолы. Минерализация рассолов ВРТ (287.4 г/д $\left.{ }^{3}\right)$ ниже минерализации рассолов ЗРТ $\left(401.5\right.$ г/дм $\left.{ }^{3}\right)$ на 100 г/дм³ ${ }^{3}$ а значения генетических коэффициентов $\mathrm{Cl} / \mathrm{Br}$ и $\mathrm{rNa} / \mathrm{rCl}$ несколько выше: 53 и 0.18 - ВРТ и 49 и 0.11 - ЗРТ. По комплексу гидрогеохимических признаков рассолы глубоких горизонтов трубки Удачная относятся к метаморфизованным и имеют аналоги на всей Сибирской платформе.

\section{5. РЕЗУЛЬТАТЫ И ИХ ОБСУЖДЕНИЕ}

\section{1. МИНЕРАЛЬНЫЙ СОСТАВ КИМБЕРЛИТОВ И РАЗРЫВНАЯ ТЕКТОНИКА ГОРНОГО МАССИВА РУДНИКА «УДАЧНЫЙ»}

Результаты определения минерального состава образцов кимберлитов показали, что кимберлитовая брекчия имеет в основном карбонатный состав: кальцита - 30-90 \%, доломита - 15-75 \%. Доля сульфатных минералов: ангидрита - 10-35 \%, силикатных: серпентина - 10-45 \%, кварца - 5-25 \%, следов слюдистых минералов, полевых шпатов, пироксена, магнетита - не более $5 \%$. 


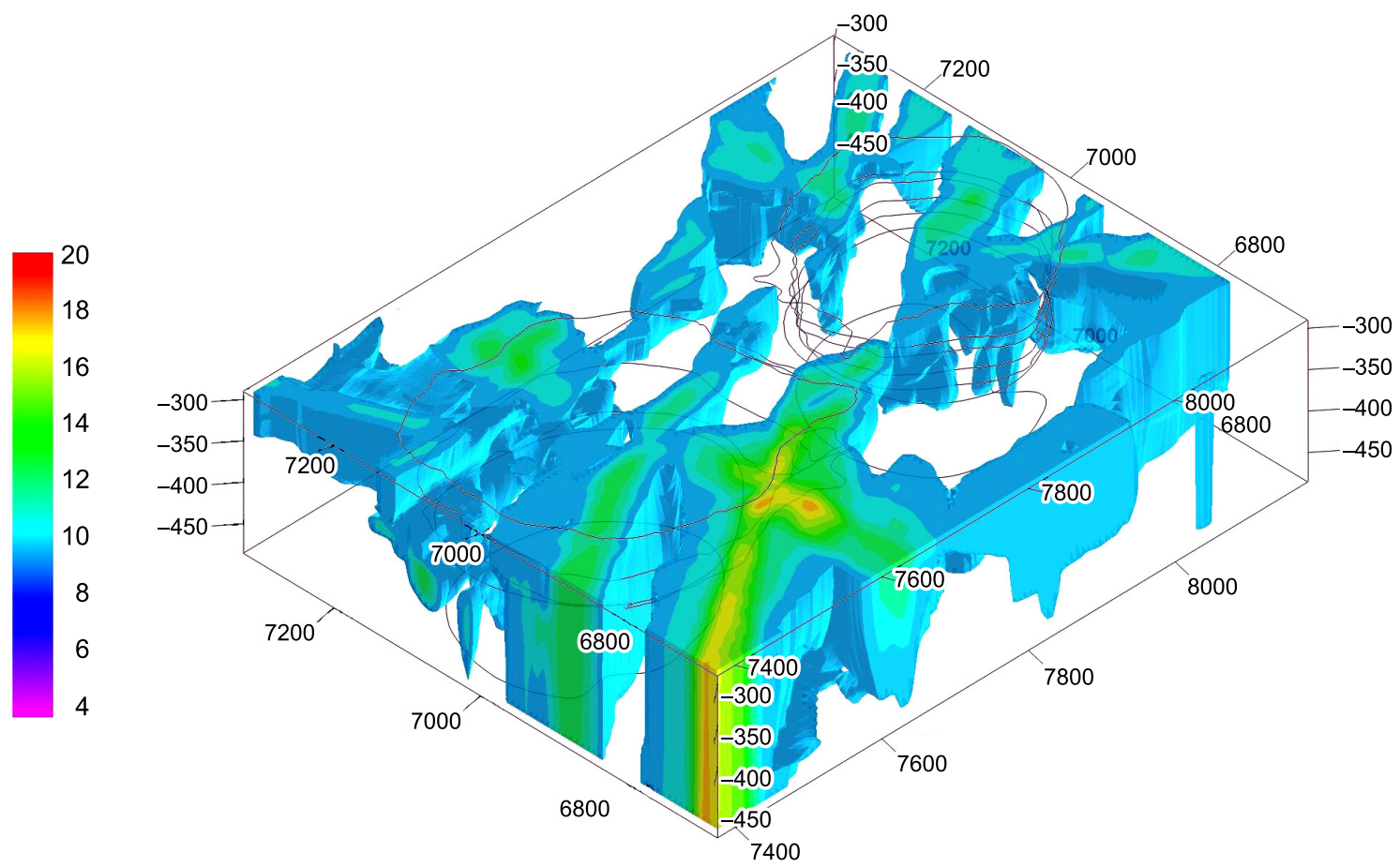

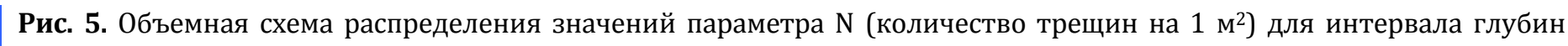
$-280 . . .485$ м абс. рудника «Удачный» (вид с юго-запада). Изоповерхности проведены начиная с 10 тр./м².

Fig. 5. Distribution of $\mathrm{N}$ values at the horizon of $-280 \ldots-485 \mathrm{~m}$ asl of the Udachnaya mine (view from SW). $\mathrm{N}$ - number of fractures per square meter. Isosurfaces are given from $\mathrm{N}=10$.

Тектонические нарушения и трещиноватость оказывают определяющее влияние на блочную делимость горных пород, степень их устойчивости, а также распределение и циркуляцию подземных вод в горном массиве.

Строение разломной сети определяется наличием нарушений: с субвертикальным падением (см. рис. 2), с наклонным падением (см. рис. 3), а также субгоризонтальных нарушений как во вмещающих породах, так и в пределах кимберлитовых тел. Субвертикальные и наклонные нарушения представляют собой зоны повышенной трещиноватости мощностью от первых метров до первых десятков метров. Субгоризонтальные нарушения представлены зонками трещиноватости и рассланцевания пород, мощность которых колеблется от первых десятков сантиметров до первых метров.

Для оценки ширины и глубины проникновения зон разрывных нарушений на основе использования параметра $\mathrm{N}$ (количество трещин на $1 \mathrm{~m}^{2}$ ), рассчитанного при помощи алгоритма Directional Weighting для 178 точек наблюдений на различных горизонтах рудника, построены трехмерные схемы в программе RockWorks2002. На рис. 5 приведена модель, которая иллюстрирует локализацию участков горных пород со значениями N, превышающими 10 трещин на $1 \mathrm{~m}^{2}$. Эти участки в силу своей нарушенности являются наиболее проницаемыми для подземных вод.

В целом, охарактеризованные выше разномасштабные дизъюнктивные структуры разбивают горный массив месторождения на серию блоков различной конфигурации, размеров и степени нарушенности. При преобладающей роли разрывных нарушений диагонального направления (северовосток-северо-запад) блоки, вычленяемые ими, зачастую имеют форму параллелепипеда, реже ромба или трапеции.

Наиболее мелкие из них (сотни квадратных метров) наблюдаются в центральной части рудничного поля, на участках взаимного пересечения нескольких разломных зон вблизи тела трубки. Более крупные (тысячи квадратных метров) фиксируются на удалении от кимберлитового тела. Степень деструкции породного массива существенно отличается в пределах рудных тел, областей экзо- и эндоконтакта и вмещающих отложений. Так, наиболее нарушенными участками являются приконтактовые области, в которых помимо тектонических трещин и разломных зон формируются трещины термической контракции, возникающие при контакте горячего расплава с относительно холодными вмещающими толщами и подземными водами. В пределах самих рудных тел возникает пара- 
генезис трещин, связанных с более поздними этапами тектонической активизации, поскольку консолидированные магматические образования ввиду разности физико-механических свойств с вмещающими толщами представляют собой то ослабленное направление, по которому легче всего происходит разрядка напряжений [Volfson, Yakovlev, 1975].

Анализ особенностей распределения водопритоков в горных выработках показывает, что основные очаги разгрузки рассолов приурочены к зонам разрывных нарушений, их узлам и участкам пересечения с контактами кимберлитовых тел (рис. 6).

Полученные структурные схемы (см. рис. 5, рис. 6) в комплексе с гидрогеологическими данными могут служить основой для прогнозной оценки водопроявлений на глубоких горизонтах рудника, которые будут вовлекаться в эксплуатацию.

\section{2. РЕЗУЛЬТАТЫ ФИЗИКО-ХИМИЧЕСКОГО МОДЕЛИРОВАНИЯ ВЗАИМОДЕЙСТВИЯ В СИСТЕМЕ ВОДА - ПОРОДА}

Исследование физико-химического равновесия и степени насыщения рассолов трубки Удачная от- носительно карбонатных, сульфатных и хлоридных минералов, характерных для рудного тела, выполнено на основе численного моделирования с помощью программного комплекса HydroGeo, который разработан на кафедре гидрогеологии, инженерной геологии и гидрогеоэкологии Национального исследовательского Томского политехнического университета совместно с Томским филиалом ИНГГ СО РАН [Bukaty, 1999b]. HydroGeo решает широкий круг геохимических задач методом констант равновесия вне зависимости от минерализации и состава природного раствора. Особенно это актуально применительно к соленым водам и крепким рассолам.

Модуль «Гидрогеохимия» программного комплекса HydroGeo позволяет выполнить наиболее распространенные типы гидрогеохимических расчетов, связанных с ионно-солевым составом подземных вод и гидрогеохимическими процессами в системе вода - порода. Важно подчеркнуть, что алгоритм, в отличие от большинства других, не содержит принципиальных ограничений по солености и ионной силе растворов. Кроме того, с помощью вспомогательной процедуры может осущест-

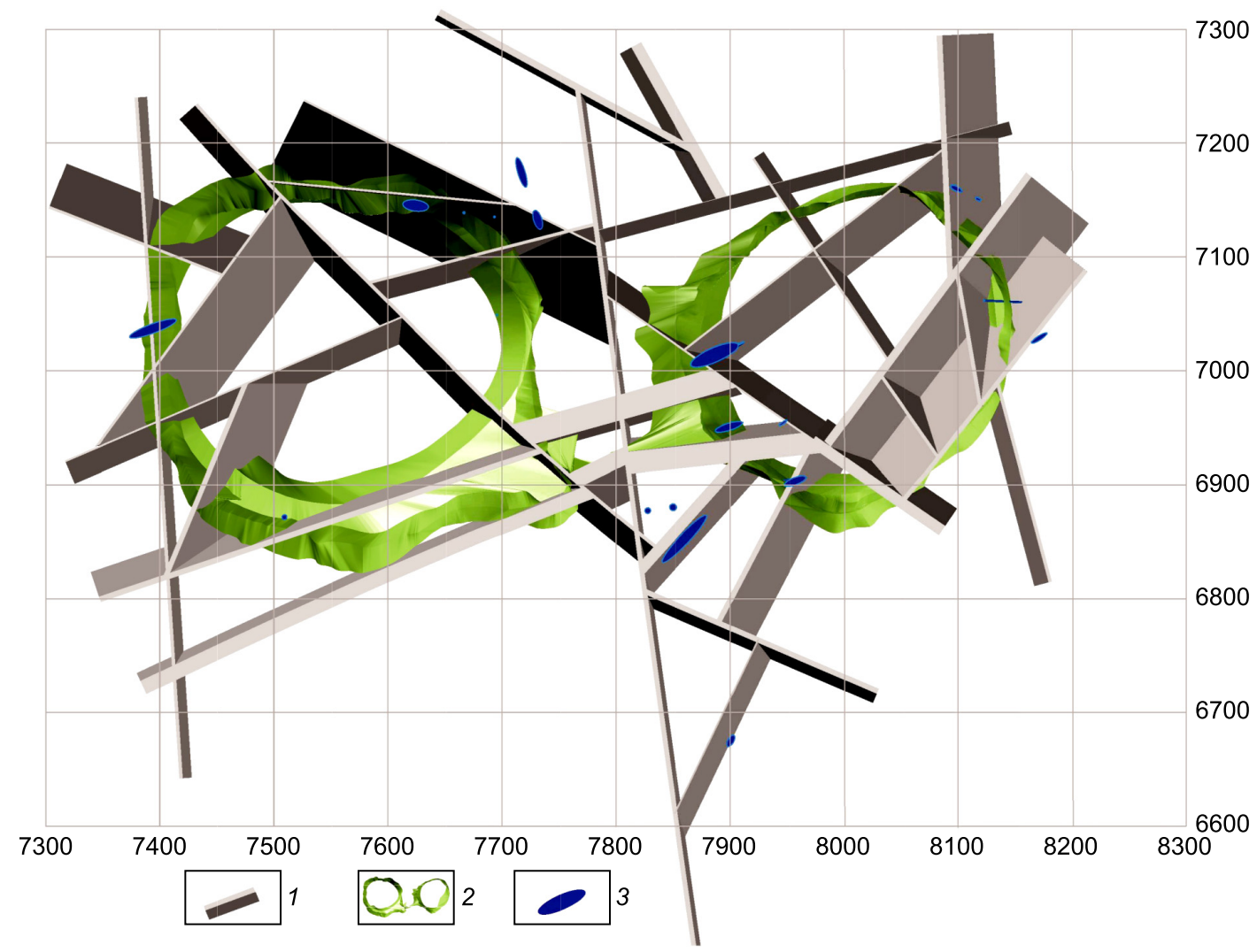

Рис. 6. Локализация очагов разгрузки рассолов в пределах трубки Удачная. 1 - зоны разрывных нарушений; 2 кимберлитовые тела; 3 - участки интенсивной разгрузки рассолов в подземных выработках рудника.

Fig. 6. Localization of brine discharges within the Udachnaya pipe. 1 - fracture zones; 2 - kimberlite bodies; 3 - areas of intensive brine discharge in underground excavations. 
Т а 6 л и ц а 2. Результат химического анализа пробы рассола, вскрытого скважиной СГК-1

$\mathrm{T}$ a b l e 2. Chemical analysis results for the brine sample from well SGK-1

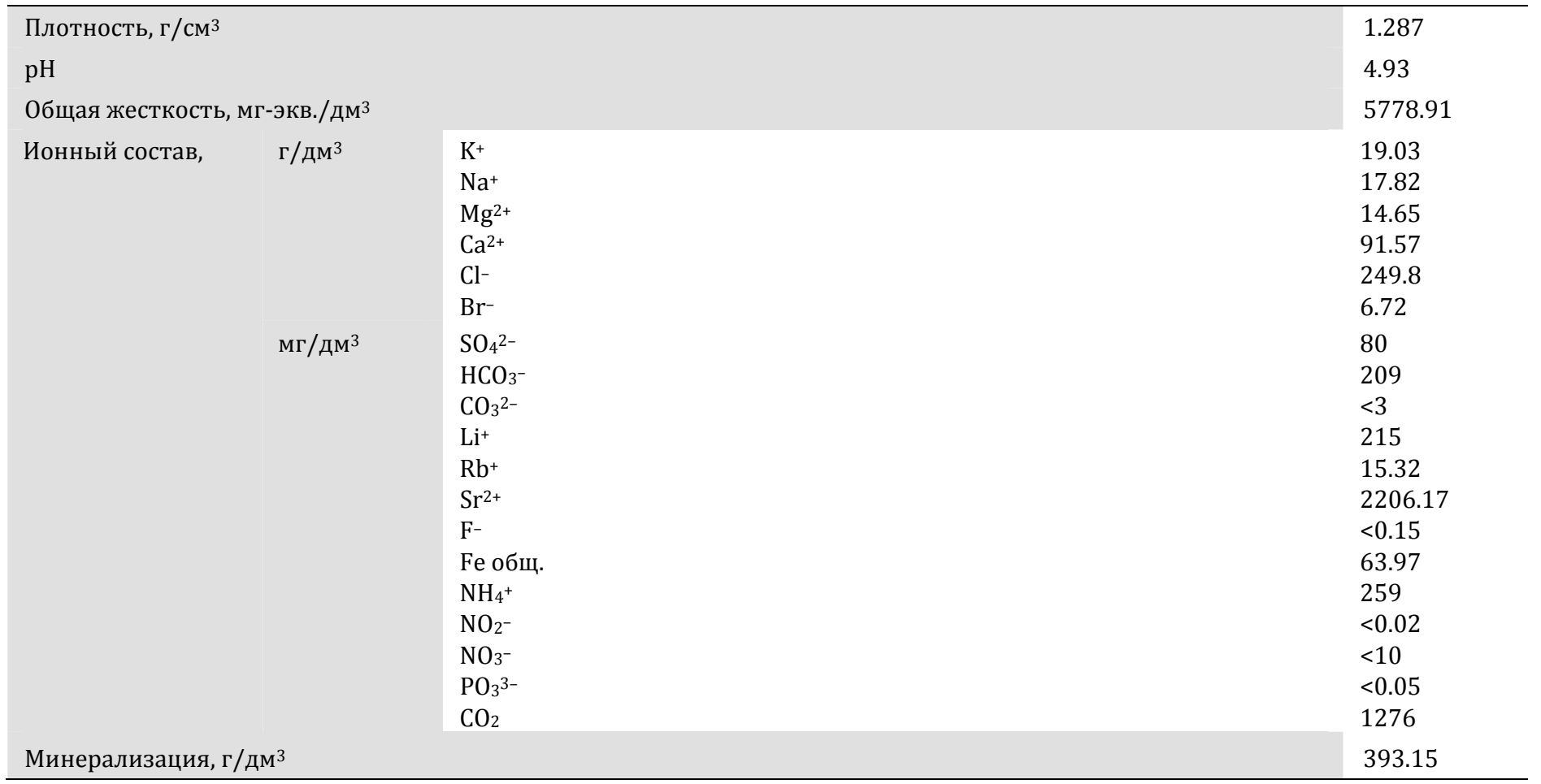

вляться выбор/перевыбор минимально необходимого списка участвующих в расчете компонентов раствора и минералов из всех имеющихся в базе термодинамических данных. Наличие такой настройки обеспечивает универсальность процедуры в отношении различных гидрогеохимических систем, включая систему рассол - порода.

Физико-химическое моделирование степени равновесия рассол - порода включало следующие этапы: 1) выбор необходимых для расчета ионов из встроенной в программный комплекс HydroGeo базы данных; 2) пересчет анализов всех используемых вод при стандартных (лабораторных) условиях для восстановления баланса электронейтральности и устранения начального пересыщения из-за возможных погрешностей анализа; 3) определение необходимого состава ионных ассоциатов, которое проводится серией предварительных вычислений с учетом максимально возможного их числа, после чего ассоциаты, не образующие в рассматриваемой системе сколько-нибудь значимых концентраций, из нее исключаются; 4) выбор из имеющейся в программном комплексе HydroGeo базы данных необходимых породообразующих и вторичных минералов, степень равновесия с которыми требуется оценить; 5) расчет активностей компонентов в стандартных условиях; 6) изменение термобарических условий раствора на пластовые; 7) повторение процедуры расчета ак- тивностей компонентов, но уже в пластовых условиях.

Расчет равновесий подземных вод с основными минералами водовмещающих кимберлитов выполнен с использованием результатов химического анализа пробы рассола, вскрытого скважиной СГК-1 в руднике «Удачный» (табл. 2).

По химическому составу рассол, вскрытый скважиной СГК-1 (горизонт -465 м абс.) и отобранный 26.07.2017 г., - хлоридный кальциевый с минерализацией 393.2 г/дм³ . Величина $\mathrm{pH}$, измеренная в лабораторных условиях, составила 4.93 .

Для оценки степени насыщения раствора относительно каждого минерала использовались соответствующие параметры насыщенности $L=\ln (K / P)$, где $K$ - константа равновесия осаждения минерала из раствора, $P$ - произведение активности веществ, участвующих в этой реакции. Отрицательные значения $L$ свидетельствуют о недонасыщении, положительные - о пересыщении, а близкие к нулю - о равновесии раствора и соответствующего минерала [Bukaty, 1999a, 1999b].

При настройке модели в систему были включены следующие компоненты (табл. 3). Открытая пористость взаимодействующей породы принималась равной $12 \%$.

Расчет активностей компонентов выполнен для стандартных лабораторных условий (температура $22{ }^{\circ} \mathrm{C}$ и давление $0.1 \mathrm{MПа)} \mathrm{и} \mathrm{различных} \mathrm{вариантов}$ 
Т а б л и ц а 3. Компоненты, включенные в программу расчета равновесий

$\mathrm{T}$ a b l e 3 . Components input in the software package for equilibrium calculations

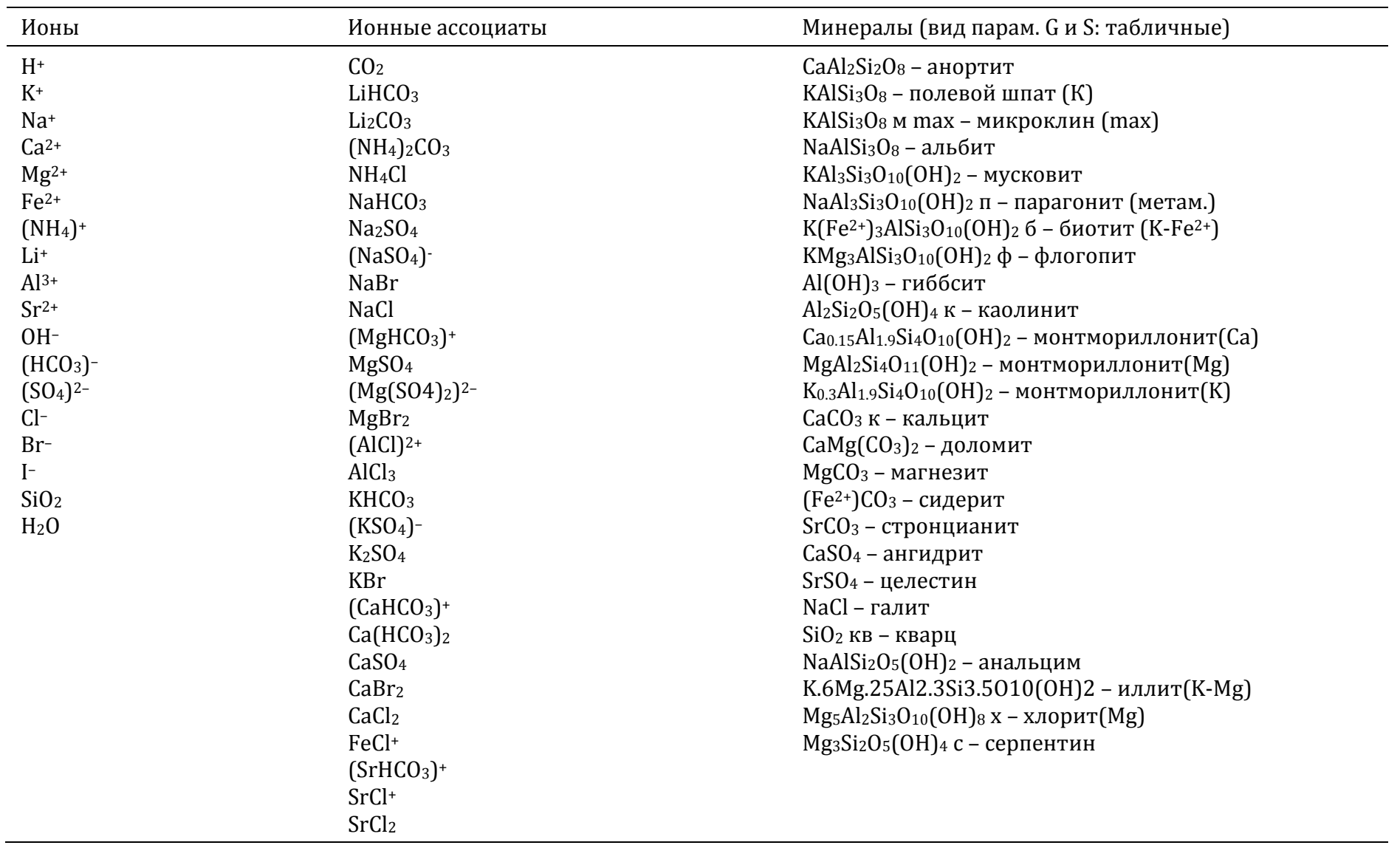

реальных пластовых условий (температура $+2,0$, $-2{ }^{\circ} \mathrm{C}$ и пластовое давление $1.4,1.8 \mathrm{MПа).}$

Установлено, что рассолы западного рудного тела трубки Удачная в глубоких горизонтах (-465 м абс.) по отношению к карбонатным минералам (кальциту, доломиту, магнезиту и стронцианиту), сульфатным минералам (ангидриту и целестину) и хлоридным минералам (галиту) резко недонасыщены (рис. 7). Параметр насыщенности L изменяется для кальцита от -0.8 до -1.2 , для доломита от -0.79 до -1.6 , для ангидрита от -2.7 до -2.8 , для галита от -1.5 до -1.6.

Неравновесность рассолов с карбонатными минералами могла быть вызвана рядом причин, например изменением интенсивности водообмена, времени взаимодействия воды с горными породами, Р-Т-условий или какими-то локальными причинами. При относительном постоянстве этих факторов в ходе геолого-геохимической эволюции Оленекского криоартезианского бассейна степень равновесия крепких рассолов с карбонатами могла также измениться в результате разбавления рассолов солоноватыми или пресными подземными водами. О дополнительных источниках маломинерализованной воды, необходимой для уменьшения солености крепких рассолов, подробно говорится в работе [Alekseev et al., 2017].

Неравновесность рассолов с сульфатными минералами предопределяется чрезвычайно малым содержанием сульфат-иона, а также отсутствием сероводорода в составе крепких хлоридных кальциевых рассолов Оленекского артезианского бассейна.

Отсутствие равновесия рассолов с галитом закономерно, поскольку содержание натрия в крепких рассолах, насыщающих кимберлитовые тела, невысокое, в среднем составляет 10-16 \%-экв, а кальций в значительной степени доминирует среди катионов. В рудных телах в этом случае не создается благоприятных условий для растворения хлоридов натрия и калия и достижения насыщенного состояния рассолов относительно этих минералов.

\section{6. ЗАКЛЮЧЕНИЕ}

Подземные рассолы, заполняя трещинно-поровое пространство в надежно изолированных глубокозалегающих горизонтах, отличаются от других 
(a) Температура $22^{\circ} \mathrm{C}$, давление $0.1 \mathrm{MПа}$

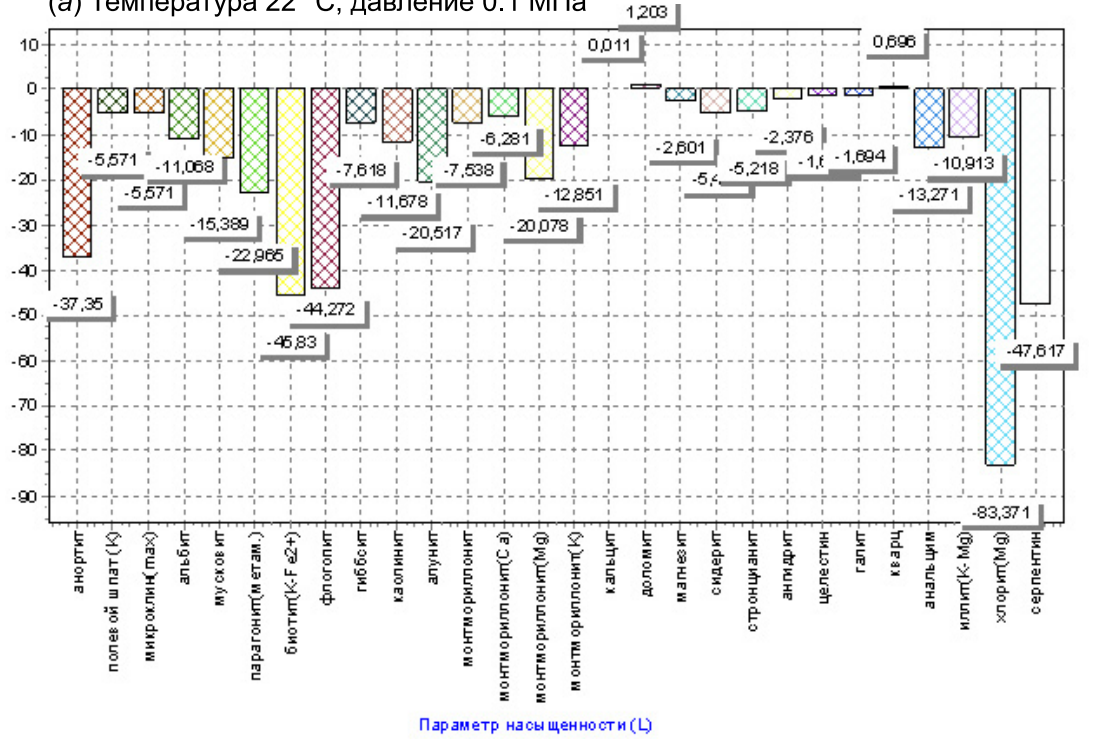

(б) Температура $+2{ }^{\circ} \mathrm{C}$, давление $1.4 \mathrm{MПа}$

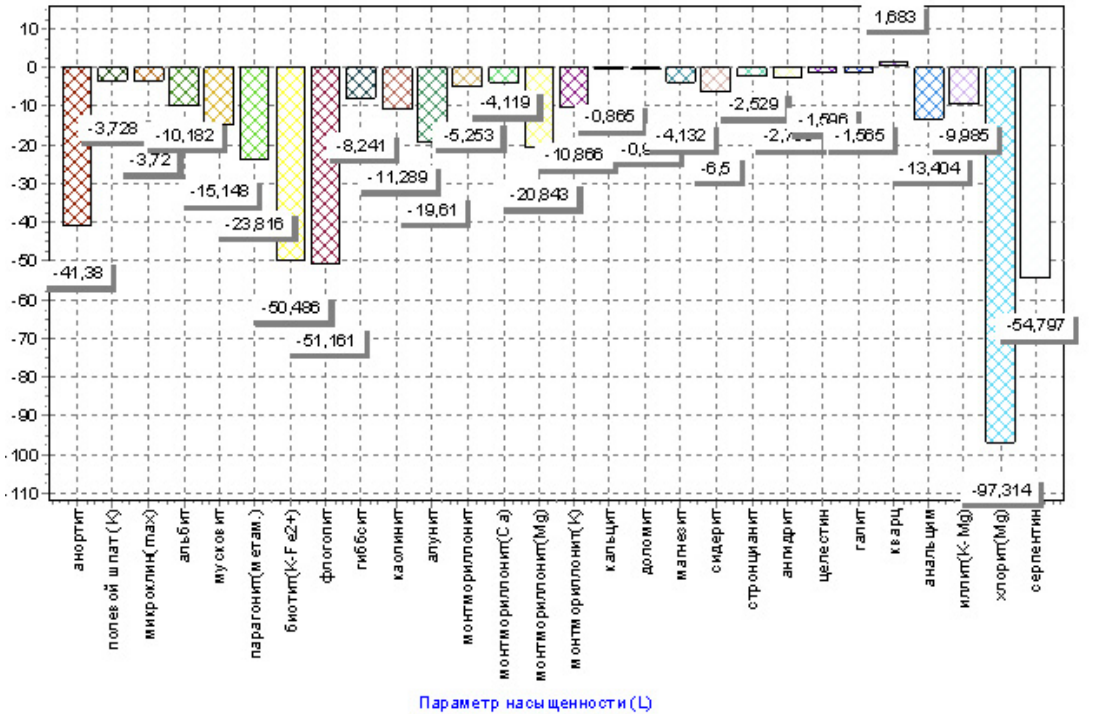

(в) Температура $0{ }^{\circ} \mathrm{C}$, давление $1.4 \mathrm{MПа}$

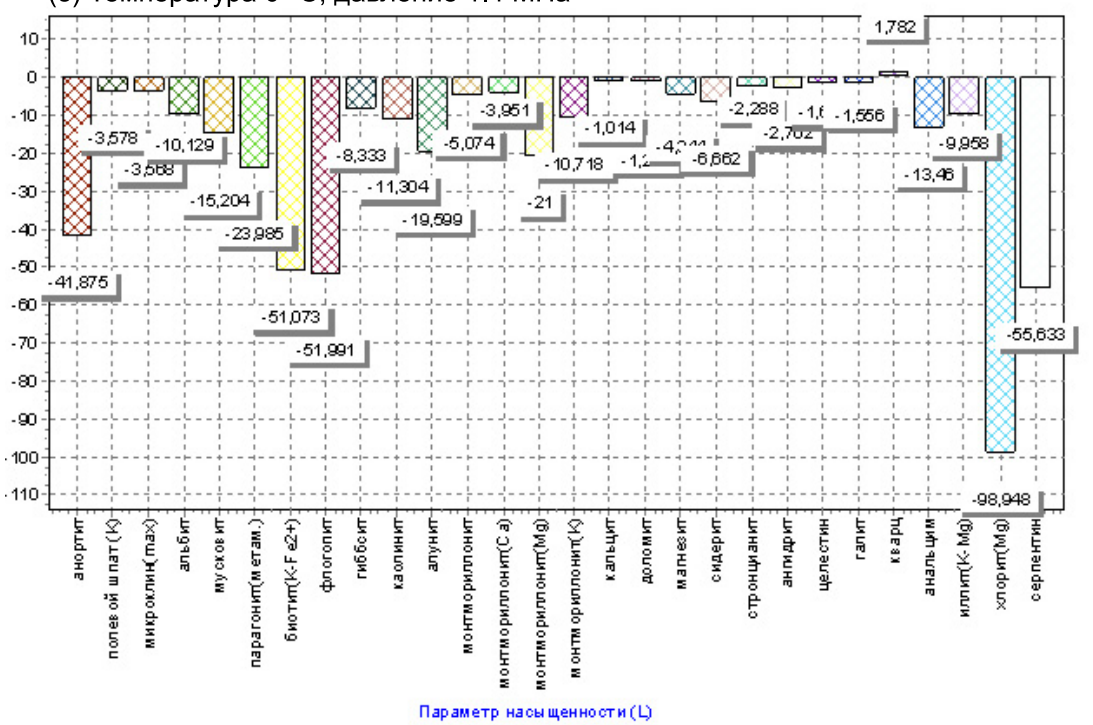

Рис. 7. Степень насыщения рассолов, вскрытых в западном рудном теле трубки Удачная, относительно основных породообразующих минералов кимберлитовой брекчии при различных Р-Т условиях $(a-ж)$ (по результатам расчетов в программном комплексе НуdroGeo).

Fig. 7. Degrees of brine saturation in the Western ore body of the Udachnaya pipe relative to the main rock-forming minerals of the kimberlite breccia at various $\mathrm{P}-\mathrm{T}$ conditions $(a-\varkappa)$ (calculated by HydroGeo software). 
(2) Температура $-2{ }^{\circ} \mathrm{C}$, давление $1.4 \mathrm{MПа}$

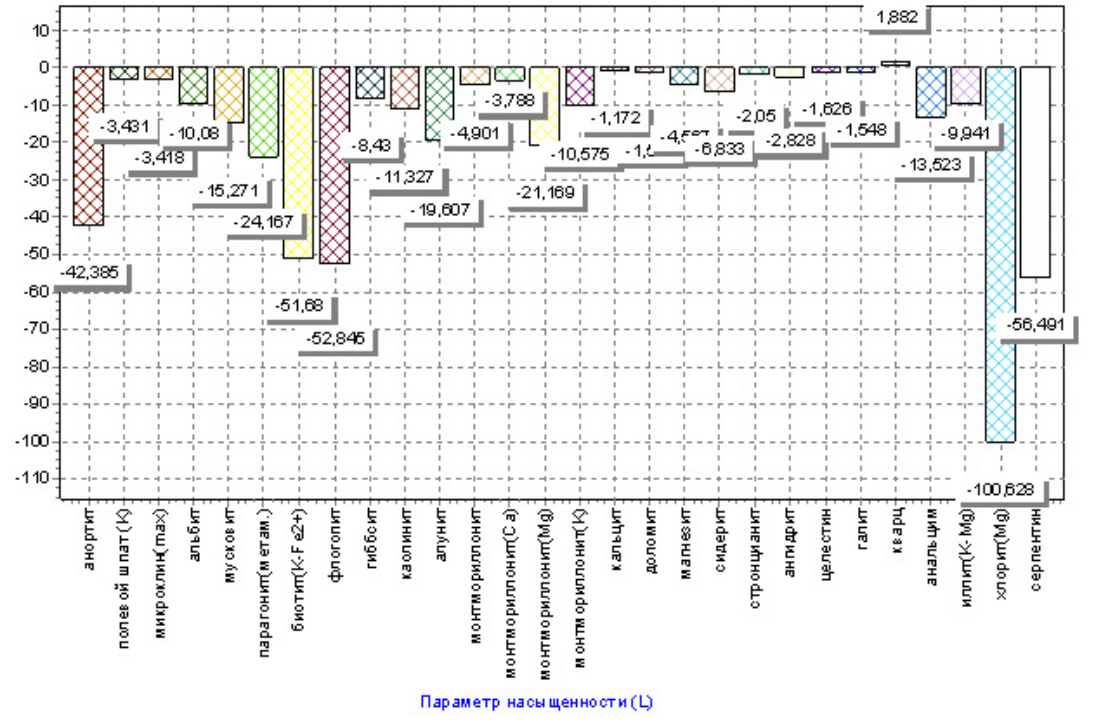

(d) Температура $+2{ }^{\circ} \mathrm{C}$, давление $1.8 \mathrm{MПа}$

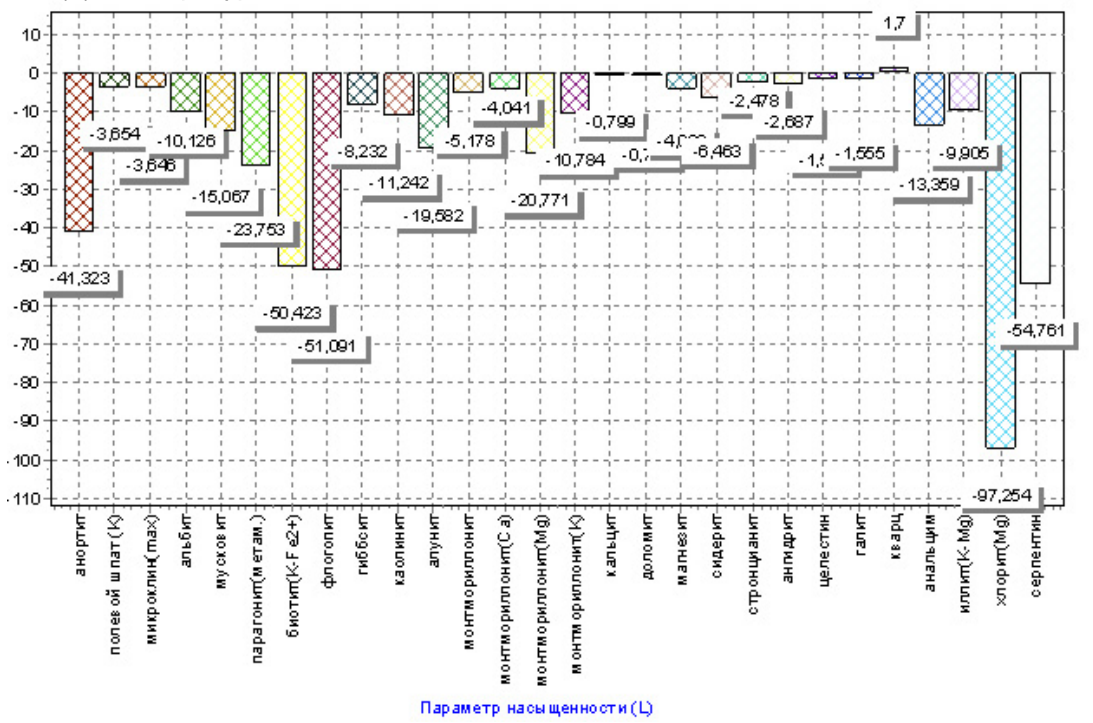

(e) Температура $0{ }^{\circ} \mathrm{C}$, давление $1.8 \mathrm{MПа}$

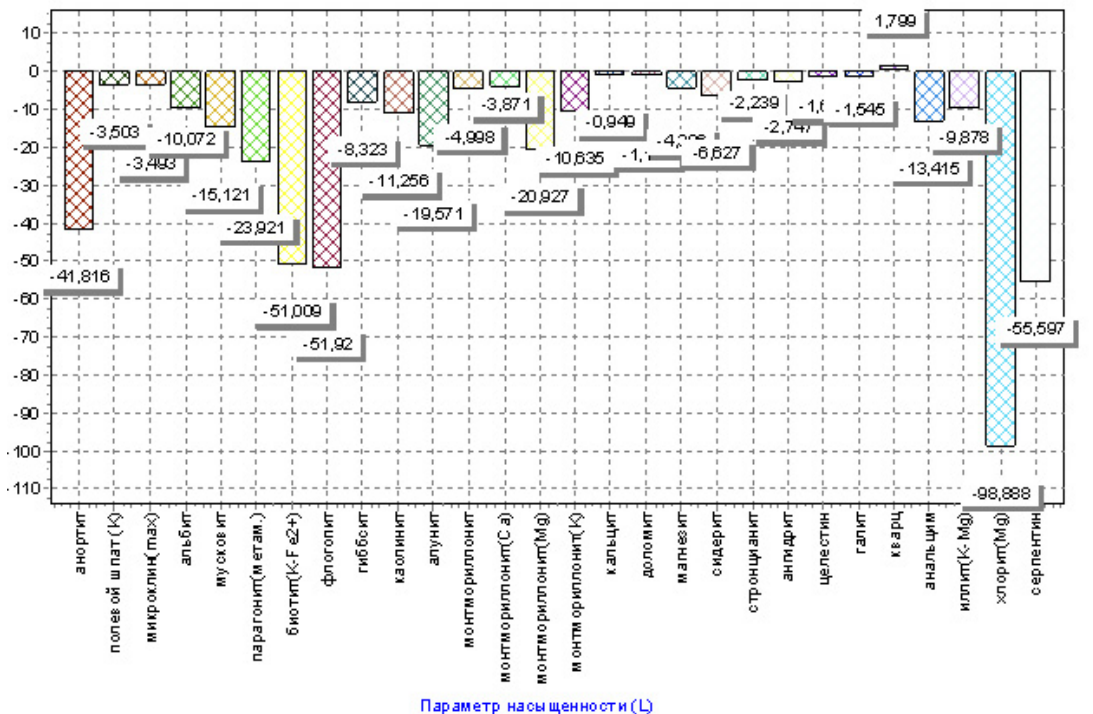

Рис. 7 (продолжение)

Fig. 7 (continuation) 


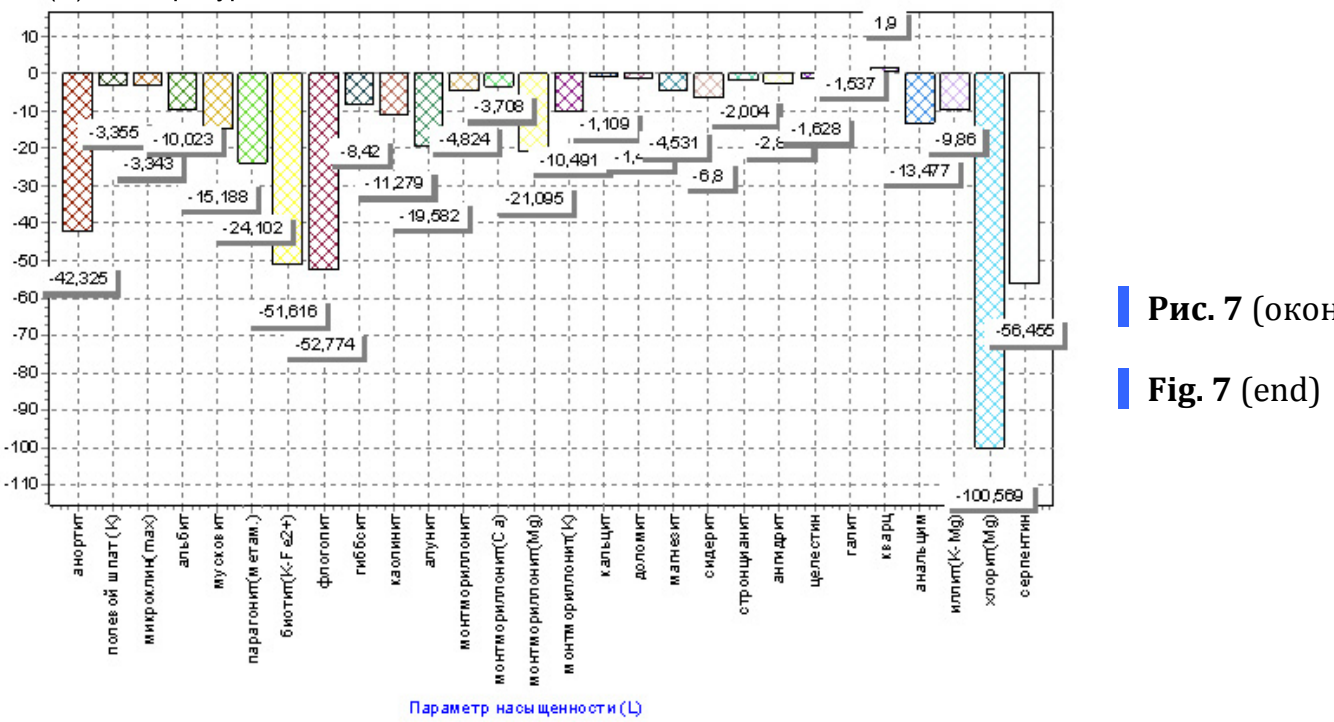

генетических типов подземных вод своим составом, высокой (до 600 г/дм³ и более) минерализацией и степенью метаморфизации. Механизмы их формирования разнообразны, но, так или иначе, геохимические особенности определялись степенью испарительного концентрирования древних солеродных бассейнов и длительной эволюцией основополагающей системы вода - порода.

В связи с этим изучение геолого-гидрогеологических особенностей кимберлитовых трубок на Сибирской платформе имеет принципиальное значение при решении проблемы формирования ресурсов, гидрогеохимической зональности и генезиса подземных хлоридных рассолов.

Особенности разрывной тектоники являются одним из основных факторов, определяющих распределение и миграцию подземных вод (рассолов) в горном массиве разрабатываемого месторождения трубка Удачная. Создание трехмерных схем разломно-блокового строения и распределения основных количественных параметров дизъюнктивных структур различных рангов совместно с результатами гидрогеологических наблюдений позволяет с высокой степенью вероятности прогнозировать участки интенсивной разгрузки рассолов в глубоких горизонтах месторождения и учитывать их при планировании и проведении горных работ.

\section{7. БЛАГОДАРНОСТИ}

Работа выполнена при поддержке РНФ (проект № 17-17-01158) и РФФИ (проект № 18-35-00452).

\section{8. ЛИТЕРАTУРА / REFERENCES}

Alekseev S.V., 2009. Cryohydrogeological Systems of the Yakutian Diamondiferous Province. Geo, Novosibirsk, 319 p. (in Russian) [Алексеев С.В. Криогидрогеологические системы Якутской алмазоносной провинции. Новосибирск: Гео, 2009. 319 с.].

Alekseev S.V., Alekseeva L.P., Borisov V.N., 2000. Dynamics of drainage water composition during mining of the diamond quarry (Yakutia). Geografiya i Prirodnye Resursy (Geography and Natural Resources) (4), 143-146 (in Russian) [Алексеев С.В., Алексеева Л.П., Борисов В.Н. Динамика состава дренажных вод при разработке алмазодобывающего карьера (Якутия) // География и природные ресурсы. 2000. № 4. С. 143-146].

Alekseev S.V., Alekseeva L.P., Shvartsev S.L., Trifonov N.S., Sidkina E.S., 2017. Specifics of the Late Cenozoic geochemical evolution of chloride calcium brines in the Olenek cryoartesian basin. Geochemistry International 55 (5), 442-456. https://doi.org/10.1134/S0016702917050020.

Brown G.B. (Ed.), 1961. The X-Ray Identification and Crystal Structure of Clay Minerals. Mineralogical Society, London, 544 р. [Русский перевод: Рентгеновские методы изучения и структура глинистых минералов / Ред. Г. Браун. М.: Мир, 1965. 599 с.].

Bukaty M.B., 1999a. Equilibrium between underground brines of the Tunguska basins and minerals of evaporite and terrigenous facies. Geologiya i Geofizika (Russian Geology and Geophysics) 40 (5), 750-763. 
Bukaty M.B., 1999b. Advertising and Technical Description of HydroGeo Software Package. VNTIC, Moscow, 5 p. State Registration Number of Algorithms and Programs in the All-Russia Scientific and Technical Information Center (VNTIC) No. 50980000051 PC (in Russian) [Букаты М.Б. Рекламно-техническое описание программного комплекса HydroGeo. М.: ВНТИЦ, 1999. 5 с. Номер государственной регистрации алгоритмов и программ во Всероссийском научно-техническом информационном центре (ВНТИЦ) №50980000051 ПК].

Gladkov A.S., Bornyakov S.A., Manakov A.V., Matrosov V.A., 2008. Tectonophysical Studies in Diamond Prospecting. Manual. Nauka, Moscow, 175 p. (in Russian) [Гладков А.С., Борняков С.А., Манаков А.В., Матросов В.А. Тектонофизические исследования при алмазопоисковых работах. Методическое пособие. М.: Научный мир, 2008. 175 c.].

Hubbard C.R., Snyder R.L., 1988. RIR-measurement and use in quantitative XRD. Powder Diffraction 3 (2), 74-77. https://doi.org/10.1017/S0885715600013257.

Kolganov V.F., Akishev A.N., Drozdov A.V., 2013. Mining and Geological Features of Primary Diamond Deposits of Yakutia. Mirny Town Printing House, Mirny, 568 p. (in Russian] [Колганов В.Ф., Акишев А.Н., Дроздов А.В. Горногеологические особенности коренных месторождений алмазов Якутии. Мирный: Мирнинская городская типография, 2013. 568 с.]

Kostrovitsky S.I., Spetsius Z.V., Yakovlev D.A., Fon-der-Flaas G.S., Suvorova L.F., Bogush I.N., 2015. Atlas of Primary Diamond Deposits of the Yakutian Kimberlite Province. Mirny Town Printing House, Mirny, 480 p. (in Russian) [Koстровицкий С.И., Специус З.В., Яковлев Д.А., Фон-дер-Флаас Г.С., Суворова Л.Ф., Богуш И.Н. Атлас коренных месторождений алмазов Якутской кимберлитовой провинции. Мирный: Мирнинская городская типография, 2015. 480 c.].

Melnikov P.I. (Ed.), 1984. Permafrost and Hydrogeological Conditions of East Siberia. Nauka, Novosibirsk, 191 p. (in Russian) [Мерзлотно-гидрогеологические условия Восточной Сибири / Ред. П.И. Мельников. Новосибирск: Наука, 1984. 191 с.].

Volfson F.N., Yakovlev P.D., 1975. Structures of Ore Fields and Deposits. Nedra, Moscow, 271 p. (in Russian) [Воль $\phi$ сон Ф.Н., Яковлев П.Д. Структуры рудных полей и месторождений. М.: Недра, 1975. 271 с.].

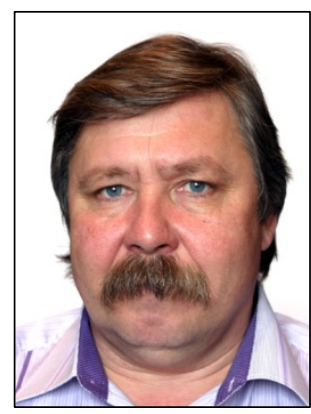

Сергей Владимирович Алексеев, докт. геол.-мин. наук, зав. лабораторией

Институт земной коры СО РАН

664033, Иркутск, ул. Лермонтова, 128, Россия

e-mail: salex@crust.irk.ru

ORCID ID https://orcid.org/0000-0002-3853-5022

Sergei V. Alekseev, Doctor of Geology and Mineralogy, Head of Laboratory Institute of the Earth's Crust, Siberian Branch of RAS

128 Lermontov street, Irkutsk 664033, Russia

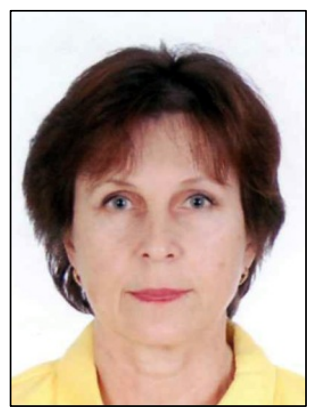

Людмила Павловна Алексеева, докт. геол.-мин. наук, в.н.с.

Институт земной коры СО РАН 664033, Иркутск, ул. Лермонтова, 128, Россия

Иркутский государственный университет, географический факультет 664003, Иркутск, ул. Карла Маркса, 1, Россия

e-mail: lalex@crust.irk.ru.

ORCID ID https://orcid.org/0000-0001-5687-4143

Ludmila P. Alekseeva, Doctor of Geology and Mineralogy, Lead Researcher Institute of the Earth's Crust, Siberian Branch of RAS

128 Lermontov street, Irkutsk 664033, Russia

Irkutsk State University, Geographical Faculty

1 Karl Marx street, Irkutsk 664003, Russia 


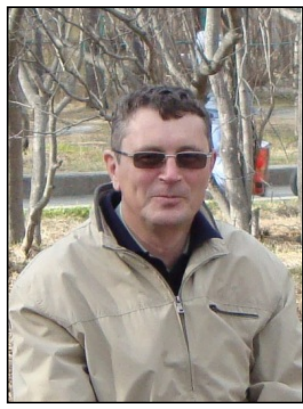

Андрей Станиславович Гладков, канд. геол.-мин. наук, с.н.с.

Институт земной коры СО РАН

664033, Иркутск, ул. Лермонтова, 128, Россия

e-mail: gladkov@crust.irk.ru

Andrey S. Gladkov, Candidate of Geology and Mineralogy, Senior Researcher Institute of the Earth's Crust, Siberian Branch of RAS

128 Lermontov street, Irkutsk 664033, Russia

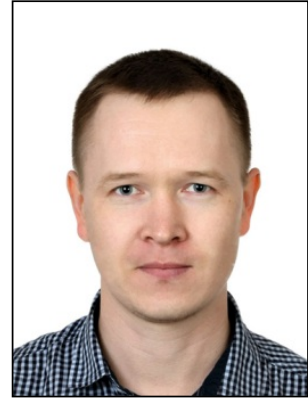

Николай Сергеевич Трифонов, канд. геол.-мин. наук, с.н.с.

Томский филиал Института нефтегазовой геологии и геофизики им. А.А. Трофимука СО РАН 634055 , Томск, пр. Академический, 4, Россия

Национальный исследовательский Томский политехнический университет 634050, Томск, пр. Ленина, 30, Россия

e-mail: trifonovnik@mail.ru

ORCID ID https://orcid.org/0000-0002-4884-7193

Nikolai S. Trifonov, Candidate of Geology and Mineralogy, Senior Researcher

Tomsk Division of A.A. Trofimuk Institute of Petroleum Geology and Geophysics, Siberian Branch of RAS 4 Academichesky ave., Tomsk 634055, Russia

Tomsk Polytechnic University

30 Lenin ave., Tomsk 634050, Russia

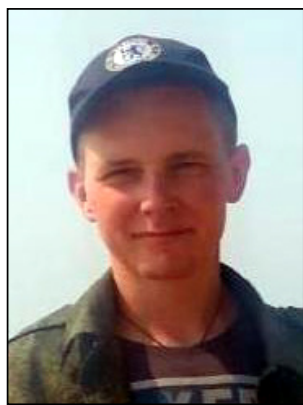

Евгений Валерьевич Серебряков, канд. геол.-мин. наук, м.н.с.

Институт земной коры СО РАН

664033, Иркутск, ул. Лермонтова, 128, Россия

e-mail:serebryakov.e.v@mail.ru

Evgenii V. Serebryakov, Candidate of Geology and Mineralogy, Junior Researcher Institute of the Earth's Crust, Siberian Branch of RAS

128 Lermontov street, Irkutsk 664033, Russia

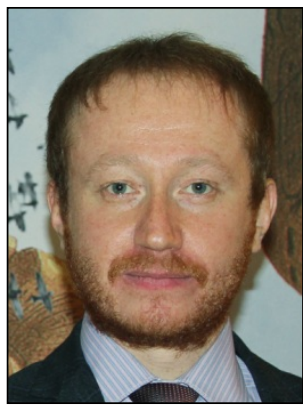

Сергей Сергеевич Павлов, главный гидрогеолог

Удачнинский ГОК, АК «АЛРОСА» (ПАО)

678188, Удачный, Новый город, Россия

e-mail: PavlovSS@alrosa.ru

Sergei S. Pavlov, Chief Hydrogeologist

Udachny Mining and Processing Division, Public Joint Stock Company "ALROSA"

Novy Gorod, Udachny 678188, Russia

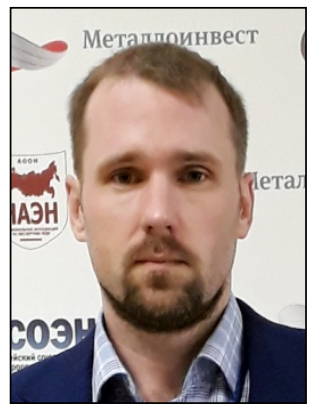

Александр Владимирович Ильин, главный специалист по гидрогеологии Вилюйская ГРЭ, АК «АЛРОСА» (ПАО)

678188, Удачный, промзона АБК, Россия

e-mail: IlinAV@alrosa.ru

Aleksander V. Il'in, Chief Specialist in Hydrogeology

Vilyui Geological Prospecting Expedition, Public Joint Stock Company "ALROSA"

Industrial Zone ABK, Udachny 678188, Russia 